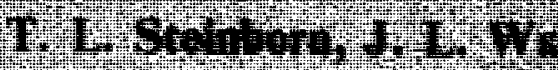

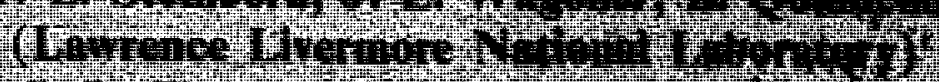

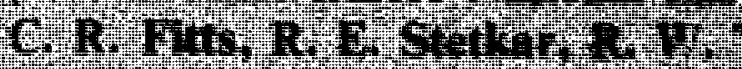

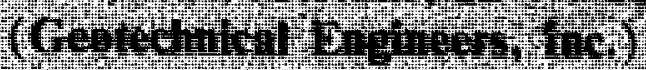

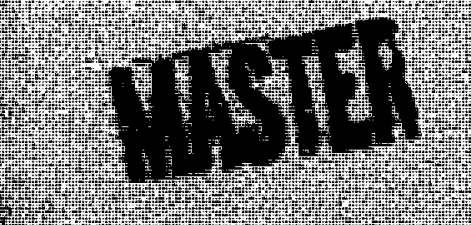

W 13)

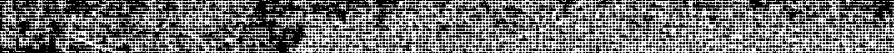
ty (1)

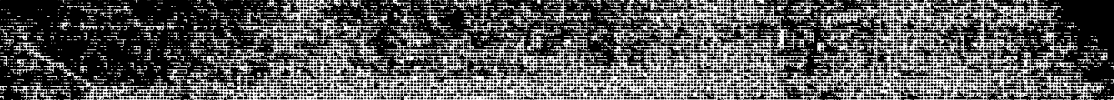


UCRL-52749

\section{Recommended new criteria for the selection of nuclear waste repository sites in Columbia River basalt and U.S. Gulf Coast domed salt}

T. L. Steinborn, J. L. Wagoner, B. Qualheim (Lawrence Livermore National Laboratory) C. R. Fitts, R. E. Stetkar, R. W. Turnbull (Geotechnical Engineers, Inc.)

Manuscript date: June 16, 1980

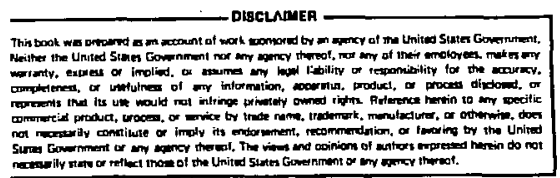

LAWRENCE LIVERMORE LABORATORY University of California $\bullet$ Livermore, California $\bullet 94550$ 
FOR EWORD

This report documents proposed criterla and screening specifications pertinent to nuclear waste repository sites in basalt and domed salt. These proposed criteria supplement general siting criteria extracted from 10 CFR 60 and ONWI $33(2)$. The discussion of these criteria addresses applications and uncertainties pertinent to geologic processes affecting waste repositories. This work was sponsored by the Office of Nuclear Material Safety and Safeguards (NMSS) of the U.S. Nuclear Regulatory Commission (NRC). The NRC FIN number is A-0277. 
Foreword

Abstract

Summar $y$

Introduction

Minimum Lateral Extent of Host Rock

Criterion 10 CFR 60.122 (c)(1)(ii)(a)

ONWI Criterion 2.1.3

Proposed Criterion

Screening Specification

Discussion

Minimum Vertical Extent of Host Rock

Criterion $10 \mathrm{CrR} 60.122$ (c) (1)(ii)(a)

ONWI Criterion 2.1.2

Proposed Criterion

Screening Specification

Discussion

Minimum Depth to Repository . . . . . . . . . . . . . . 10

Criterion $10 \mathrm{CFR} 60.12$ ?(0)

ONWI Criterion 2.1.1 • . . . . . . . . . . . . . . . . . 11

Proposed Criterion . . . . . . . . . . . . . . . . . 11

Screening Specification . . . . . . . - . . . . . . . . 11

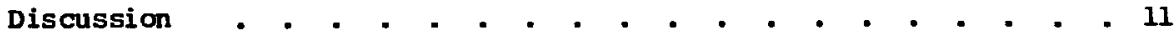

Maximum Depth to Repository . . . . . . . . . . . . . . . . 14

Criterion 10 CFR 60.122 siting . . . . . . . . . . . . . . 14

ONWI 2.1 Criterion I. Site Geometry . . . . . . . . . . . 14

Domed Salt . . . . . . . . . . . . . . . • . . . 15

Proposed Criterion . . . . . . . . . . . . . . . . 15

Screening Specification . . . . . . . • . • . . . . 15

Discussion . . . . . . . . . . . . . . . . . . 15

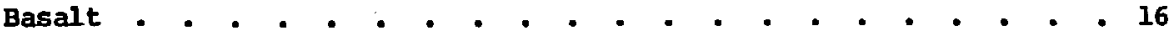

Proposed Criterion . . . . . . . . . . . . • . . . 16

Screening Specification . . • . . . . • . . . . . . 16

Discussion . . . . . . . . . . . . . . . . . . 16 
Seismicity

Criterion 10 CFR 60.122 (b) (2)(vi) . . . . . . . . . . . . . . . 17

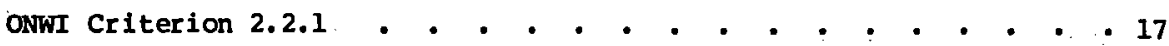

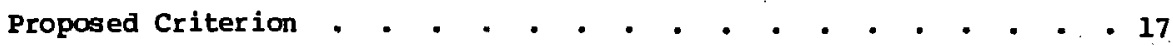

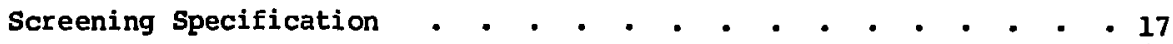

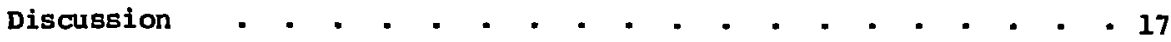

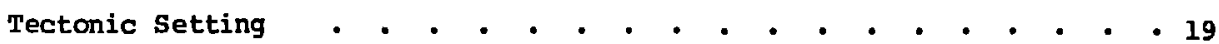

Criterion $10 \operatorname{CFR} 60.122$. . . . . . . . . . . . . . . . . 19

ONWI Criterion II. Tectonic Environment - . • • • • • • • • 19

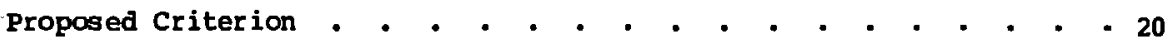

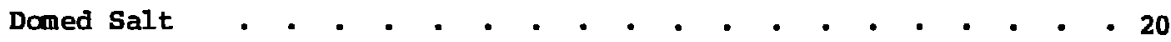

Screening Specification 1 - . . . . . . . . . . . . 20

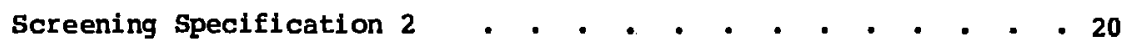

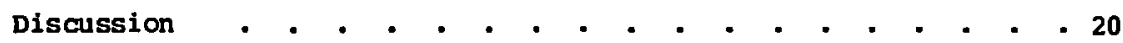

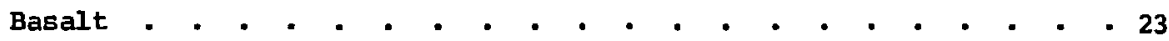

Screening Specification . . . . . . . . . . . . . . 23

Discussion . . . . . . . . . . . . . . . . . . . 23

Structural setting • . • • • • • • • • • • . . - • • 24

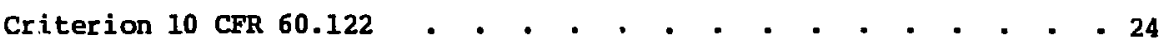

ONWI 2.2 Criterion II. Tectonic Environment _ - • • • • • - • 25

ONWI 2.5 Criterion V. Geologic Characteristics . • . • . . - 25

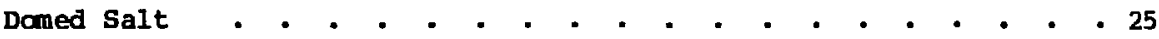

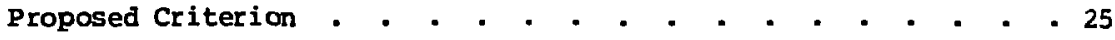

Screening Specification • • • • • • • • • • • • • . 26

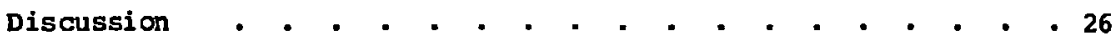

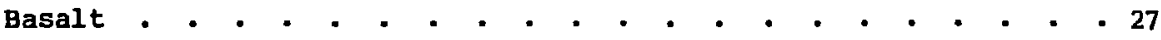

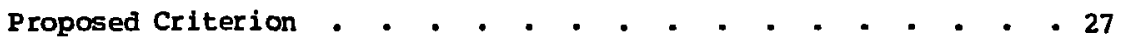

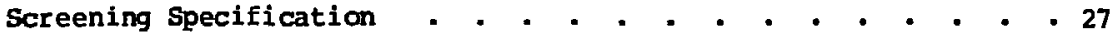

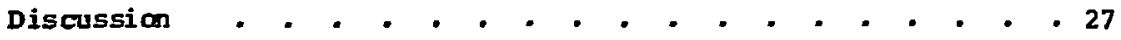

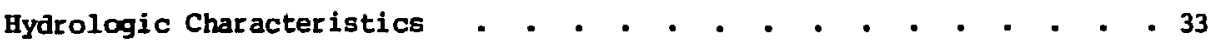

Criterion 10 CRR 60.122 siting . . . . . . . . . . . . . 33

ONTI 2.3 Criterion III. Subsurface Hydrology and Geochemistry • • 34

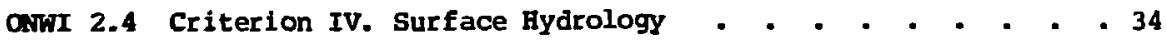

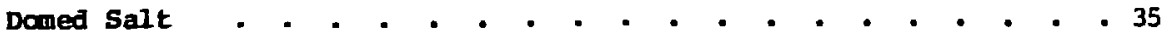

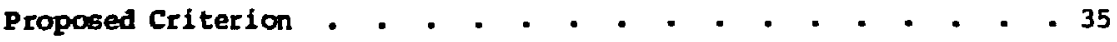


Discussion

Basalt

Proposed Criterion . . . . . . . . . . . . . . . . 38

Screening Specification . . . . . . . . . . . . . . 38

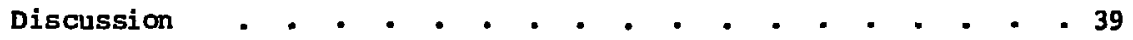

Geochemistry-Groundwater . . - . . . . . . . . . . - 42

Criterion $10 \mathrm{CFR} 60.122$ (c)(1) . . . . . . . . . . . . . . . 42

ONWI 2.3 Criterion III. Subsurface Hydrology and Geochemistry • 42

Proposed Criterion . . . . . . . . . . . . . . . - . 42

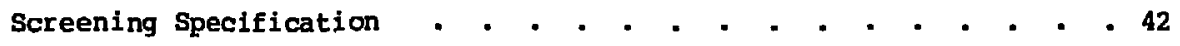

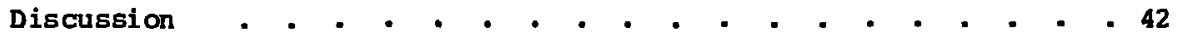

Geochemistry--Rock . . - . . . . . . . . . . . . . . 43

Criterion 10 CFR 60.122 (b) (4) . . . . . . . . . . . . . . . 43

ONWI 2.3 Criterion III. Subsurface Hydrology and Geochemistry . . 44

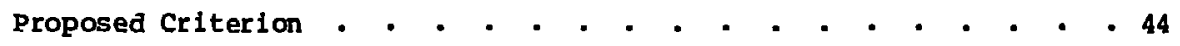

Screening Specification . . . . . . . . . . . . . . . 44

Discussion , . . . . . . . . . . . . . . . . . . 44

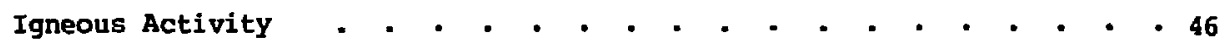

Criterion 10 CFR 60.122 (b)(2)(vii) . . . . . . . . . . . . 46

ONWI Criterion 2.2.3

proposed Criterion . - . - . . . . . . . . . . . . . 47

Screening Specification . . . . . . . . . . . . . . . 47

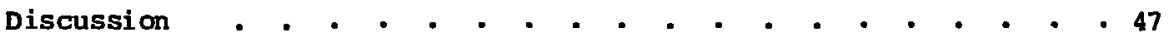

Natural Resources . - . . . . . . . . . . . . . . . . 49

Criterion 10 CFR 60.122(b)(1) Potentlally Adverse Human Activities . is

ONWI 2.7 Criterion VII. Human Intrusion . . . . . . . . - . 49

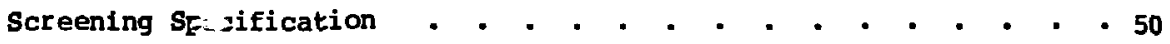

Discussion . : . . . . . . . . . . . . . . . . . 50

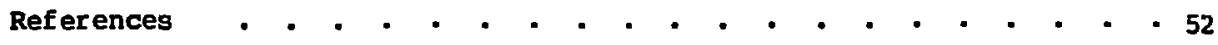


भî! 
ABSTRACT

Screening criteria and specifications are recommended to aid in the evaluation of sites proposed for nuclear waste disposal in basalt and domed salt. The recommended new criteria proposed in this report are intended to supplement existing repository-related criteria for nuclear waste disposal. The existing criteria are contained in 10 CFR 60 sections which define siting criteria of the Nuclear Regulatory Comission (NRC), and ONWI 33 (2) which defines siting criteria of the Office of Nuclear Waste Isolation (ONWI) for the Department of Energy. The speciflcations are conditions or parameter values that the authors recomend be applied in site acceptance evaluations. The siting concerns covered in this report include repository depth, host rock extent, seismic setting, structural and tectonic conditions, groundwater and rock geochemistry, volcanism, surface and subsurface hydrology, and socioeconomic issues, such as natural resources, land use and population distribution.

\section{SUMMARY}

The proposed criteria and specifications in this report are designed to supplement the general siting criteria for nuclear waste repositories as established by the NRC and ONWI, contained in documents 10 CFR 60 and ONWI 33(2), respectively. Twelve geologic parameters are addressed, which relate specifically to nuclear waste disposal sites in basalt and domed salt. For comparison, an abridgment is provided of existing and proposed criteria germane to each of those parameters (Table 1).

\section{INTRODUCTION}

The safe deep geologic disposal of nuclear waste depends on an adequate site or group of sites. Nonmedia specific criteria for site selection and 
TABI. 1. Summary comparison of site qualification criteria.

Einting critaria foc endiata roposienries

1. Mrieu Iateral extent of hat rock

2. Minieuse vertical extent of hoat rook

3. Mninie depth to reposit tor

4. Mxinun apth to reposi tory

\section{5. galeidelty}

6. Tectaific setting

7. Struetural geteing

6. Hydrologie characteriste
Long grounduter ronldonce t lane and Iong E10 pathe provided prior to entering accessible envircment

Long groundwater residence timer and lang glow pathe pravided pricr to entering accestible envi ronent

Bvidance ef processed which have caused ontrobe bedrack Imeinlon ninc Quaternary poriof Volue asalued to extend a 2-k britental distares and a l-lo vertical dibtance fro surface to a excapation

Ho rapositeory in in ares of concentrated earthquake activity relative to regional diatr lbution of earthaukes of uhere Indication that earthruakes o where Indicat costipute cotitity soy be dietribution ar frecuency of di otr lbution ar frequenry of oceurzence or correlation of
earthquaker with tectonle procosace ind feature:

Patential diverse natural conditicra--geologic and tectonle

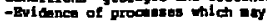
reaut in atructurel deforestion, zuch as uplift, dippirio, mbal tanca, -zuldance if 1 mitual re 1 greour activity aince ctart of Quaternary perivity

Potential acterae nutural conditicne-geologic and tectonic -Evidence of processes which ay reault in atfuctural daformatica, such as uplife, dieplefe, nubildance. rolding, foulting, or tracture sones Geologic oparation area liee vithin nes teld of I Fmit that has beet active sinco the Quaternary Period - Peult or Iracture zone vhich has a har ixontal extent of nore that a Ee hunbred aeter:

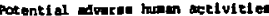
Potential dowrat ham action -Drililng, except holea for imventightion of the grologie reponitosy, to dopthe below Iner

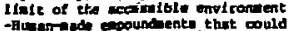

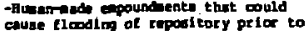
deconisstonlog

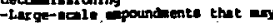
atlect reglonal ground ater flow oyece

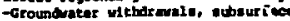
injection of elislan, undaground punped stor $\rightarrow$ to Eelilites, or underground lileary activitien

Patentiolly odverse netur 1 condiciene--hydrolonic - Slgnificent chengas in hydrauzic gradi ente, aver age pore velocitica. storativitien, purablilited, natural diseherge

whin 10a-your teod plainf

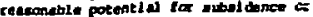
volcenle extivity to create large-sen le epoundinents that mor aftect regionil groundwater tlow syate
Bufficient acoomation of repository urkfrgur repository perfoctence not affected by conatruction and vaste arolont

Eufficient accesodation of repository orkinger repost tory portorence nol aflected $b$ construction and waste eplecent

Credible naturel proceasen at aurface al io affect to repes l tory par fortemce

Gealogic enviroment with geconetry dequite ECr rupository epil acentent hait rock thichness at repository

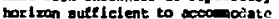
repositery urifing and to envure that irpact fro contrurtion and wastc eplactent of m unaccoptable effect to ropoed tory gerforinater

Irponitory alte located to that ground notion assoclated with wailing credible mrthouke will hive mo unacopptable dporae lopect on

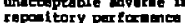

Hepostory loched a that erealble tectonic ovents are ghoom to caub unacentuble reduction in repont tory partorninal long-tern, continui pg urlift oc aubldence zates are ohom on heve $m$ edrorw ispact on repall tory per tocmonce

Inpoultory located so that credible

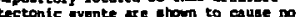
unacespeebie reduction in repository per forence: guternary f wille can be identified and shown to have no unacxpetuble dorrae iepuct on reposil tory performance

repository ilte thall nve goologie character intice compatible with waste feolation; atratigraphlc setting can be suftielenty dell ned to pernit modeling as pert of ropost tory rystem

Rereitory aball have suburfice hydrablic and geoch int hydrable and geoch-aical with wate toolation

1wolation - Bydralogleal and challan reglare prevent radi conuclidat from leavid rapostery and eransporting to opetilication

fyydrological ragit allore contruction of repository shafts and ani atenarua of aheft il nert by state- of-the-axt seans

- Buburface rock alagolation ahoun to have no uniccoptable arerine lipect on partorance af siponitory

Surticial byarologlenl ayatea during cliantic crelea and ent rease natural phen. averis lapect on repost toty parformenc
Acequate prea to oparate reposi tory? euffiel entily wide butfer pore of undisturbed rock on all alden to enirure contaf ment

Bufficient to preclute breaching of geologle contai nent

Ropal tory at autficlent depth to Beparate repoiftory I rom surfigiel procengen and other cradihle erente that could teavit in hasardoug breach

Doned galts repository atrear af hast rock and aurrounding tocts bes not jeopardico conatruction. operation. and phyalcal integrity of repository Bespitts hydrologie and etructur al properties pose on jeopardy to phyoical integrity of repository

Aepoal tory site to locsted that ground

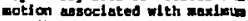
crediblo earthquale will have no uracoptable ifpet on reporitory unacteptebl

Repository will be located in an area where rate and asount of long-term uplift or aubsidence poses no threat to repository contal jeent

Doaed anle: faults and other atructural discontinul ties at or nesr reponitory cite ahnll not jeoparalre cophervetion, operation, or geologle conntruction, operation, or contsi rent of repoditory
Ansalts faults or atructural discontl nuteles (Jointw) In or near reponi tory al to ahould not feopardize centeruction, operation, or long-term geologic ontai ment of rapository

Doned galt: repontrory ghall be Dached in a galt don that is bydrologically atable, or thete diseolution of selt is of mo uncroptable efrerue lopace on

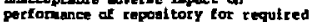
period of containent

Earalt: reponitory thall be located in - baeale rock that hai no hydralogic ehurneterinefes of edverbe ipact on per tarmence of reponticory for requi red period 
TABIE 1. (Continued.)

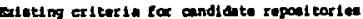

Parenger

9. Geochediutry grounduter

10. Geochenlatryrock

11. tgneous agtivity

12. Gakural rewourcese
Bout rock and aur rounding confining mite provil pochend cel propartia,

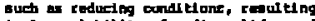
In Iow solubll fty of radicnuclidan and

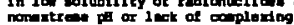
crents thes prowece hich retardition oftents thist proa

Absence of geochenteal proparties that provlda aejor bateler to the wowerent af noot radicnuclidat betwen ropodtery and acesesible envirorent

Evidence exiate of laneous activier ince the start of the quiternary Perlod

Past of precent suburface elning for resourceni past oc prasent dilling. - seopt for invert gatian af gealogic repoltory, to dopthe below laver lialt of accenal ble enviroment. pesourcan are econcil eally erplot tenkle uting technolow under probunt enekt conditions, Dnuur ons have higher grour or net valu than for ncer-al zed grees in the geologie provines. Daterainntion of not vilu mhil Datereinntion of net val engil Gnidir me velu, dorlopent,

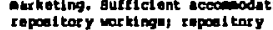
repoed tory warkingu' repoed tory condtruet ion ind waste esploctent
Offion of puelear Wate Ioolation $\operatorname{con} 33(2)$

Rocconended now criteria
Eydrological and gecoben cal reqies prevente codicnucliden from tesoing cepository on teraneporting to the Maptere in mounts ox levele above thost opecified

Hydrologionl and geocheateal terte preventis radionuelidas froe lesulne repoit tory and treneporting to the biophare in counts of levele above thon mecifind

Centere of Quaternaxy igneous activity cen be ldontified and can be aboun to can no unmecoptable adveras lapect on repolt tory perforemes

Likelinood $\alpha$ consequencel of past or luture hum Intrueion w11 cause no

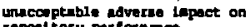
reposel tory pert oxema Future Int:zulan due to at tele contalning, of upparing to conteln. ecomelenily explolteble deponita of petroleu or elnerel resources would

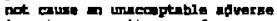

iopeat on repoul tory perforaince

Eplaration hintory of tbe aiti cen be Eploration hintory of tbe afte cen uninad and on be down to have unucciptible adversd
Groundater in repodtory host rack or in effecont quitern nunt bov chesical characteristics such that canister corrosion, wate frem

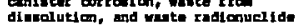
aigration ar mot peceoted

Heat rock and surtounding toek wut haw chenlcal cherscterlatlcu such that cenister corroulon, unite fra diasolution, and waste radionuelide elgration are not pronoted

inpoulecty ohall not be loented in en

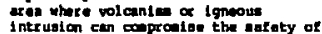
intrusicn cten copronise the antaty

No quanticative lint on the vilue of resource on be propered lax any mediu. A thorough resource imsetigation ta required for anch olte, alnes veonolic fectore are alteand ar kot-dependent 
acceptance have ieen proposed in the literature (e.g., Office of the Federal Register (OFR), 1980; Office of Nuclear Waste Isolation (ONWI), 1980; Wagone: and Steinborn, 1979; National Research Council/National Academy of Sciences (NRC/NAS), 1978; International Atomic Energy Agency (IAFA), 1977). This report proposes criteria and specifications for acceptance of repository sites in domed salt and basalt. These proposed criteria and specifications may be considered supplemental to the general siting cr teria referenced above. Topics covered include depth and extent of repository rock body, surface and subsurface hydrology, geochemistry, structural and tectonic setting, diapirism, seismicity, and natural resources. Geographical and sociopolitical considerations, such as population distribution, land status, and transportation, are not included in this report, since they depend on essentially political decisions and are not explicit technical concerns of the site. Such considerations will be important, but can be quantified only after political decisions and operational phase analyses have been made.

This report presents proposed criteria and screening specifications germane to criteria cited from $10 \mathrm{CFR} 60$ and ONWI-33(2). Each subject criterion is followed by a discussion of applications and uncertainties pertinent to sites in domed salt and basalt. The basalts considered in this report are restricted to the Columbia Plateau. Important supplementary documents to this report include a series of papers summarizing the state-of-the-art of predicting the effects of various natural geologic processes on waste repositories, produced for Lawrence Livermore National Laboratory (LWNL) by Geotechnical Engineers, Inc. (GEI), 1980a, b, $c$, d. Information presented in this report is referenced wherever applicable, but many of the conclusions stated are the professional judgment af the authors.

MINIMUM LATERAL EXTENT OF HOST ROCR

CRITERION 10 CFR 60.122 (c) (1) (ii) (a)

The site shall be selected so that to the extent practicable the candidate area contains a host rock and surrounding confining units that provide a geologic framework, such as extensive vertical and lateral continuity, that provides long groundwater residence times and long flow paths prior to entering the accessible environment. 
The lateral extent of host-rock units a': the repository horizon shall be sufficient to accommodate repository workings and to assure that imparts induced by construction of the repository and by waste emplacement will not unacceptably affect repository performance.

PROPOSED CRITERION

The repository rock unit shall have sufficient lateral extent to provide adequate space to develop and operate the repository and to provide a sufficiently wide buffer zone of undisturbed rock on all sides that ensures containnent of the waste.

\section{SCREENING SPECIFICATION}

In domed salt, the repository shall be located such that sufficient lateral extent provides a barrier of salt $500 \mathrm{ft}(153 \mathrm{~m})$ wide around the entire repository. The minimum radius required for a salt dome will depend upon the size of the repository to be cons ucted in a given dome.

For screening purposes and in the absence of data to the contrary, basalt flows will be assumed to have sufficient lateral extent to develop and operate a repository. The effect of excavation drilling and blasting, exploratory boreholes and shafts, joints, fractures and other rock mass inhomogeneities on the potential for radionuclide migration shall be corsidered in establishing the minimum lateral extent of undisturbed basalt around the repository site.

\section{DISCUSSION}

The repository host rock must be wide enough to accomnodate all of the underground working 3 and facilities and to provide a sufficiently wide buffer zone to minimize disturbance of surrounding rock and ensure containment. The buffer zone must be wide enough to absorb fractures emanating from the repository and relieve stresses produced during construction, provide adequate heat dissipation, and prevent repository breachiog by natur-1 or man-made processes. The size of the reguired buffer zone will depenc on stresses 
induced in the host rock by repository excavation and thermal expansion; waste thermal output of canisters and heat transfer characteristics of the host rock; thermal, mechanical, and chemical properties of the host rock and its lateral homogeneity; the hydrologic stability of a candidate salt dome; and the resistance of basalt to erosional or destructive processes.

Brunton et al. (1978) report that the preconceptual design for a waste repository in a salt dome requires a minimum total circular area of 1000 acres (radius $=3724 \mathrm{ft}$ ). Information compiled by Anderson et al. (1973) indicates that for 26 salt domes for which data were available the radii of the domes ranged from less than $1500 \mathrm{ft}$ to about $9000 \mathrm{ft}$, and averaged about $3000 \mathrm{ft}$. To require that a salt dome must have a radius of at least 3724 ft plus an additional thickness of salt to act as a barrier may be too restrictive and could eliminate many otherwise acceptable salt domes. Therefore, for screening purposes, the specification for this criterion is that the dome should have sufficient lateral extent to provide a barrier of salt $500 \mathrm{ft}$ $(153 \mathrm{~m})$ wide around the entire repository. The minimum radius required for a salt dome will depend upon the size of the repository to be constructed in a given salt dome.

A preconceptual design for a waste repository in basalt, developed by Parsons, Brinckerhoff, Quade \& Douglas, Inc. (PBQ\&D) (1978), requires a minimum area of approximately $8 \mathrm{~km}^{2}$. Stratigraphic studies of the lateral continuity of basalt flows in the columbia plateau region indicate that during their emplacement the flows spread out over great distance and are generally continuous over. hundreds to thousands of square kilometers (Rockivell Hanford Operations, 1978). Moreover, within the central portions of the dense flow, horizontal and vertical variations are insignificant except for minor anisotropy induced by random local jointing (PBQ\&D, 1978) and generally the flows can be considered laterally homogeneous in terms of mechanical, thermal and geochemical characteristics for hundreds of square kilometers (Rockwell Hanford Operations, 1978):- Therefore, for screening purposes, the specification assumes that the Columbia River basalt flows will have sufficient lateral extent to accommodate a repository facility.

The required width of undisturbed basalt around the repository site shall be determined by the characteristics of the repository, the properties and homogeneity of the local basalts, and the effects of local subsurface penetrations. It is likely that the brittle failure behavior of basalt will 
allow more widespread fracturing under construction and thermal loads than the: plastic behavior of salt, and, conseguently, a wider buffer zone may be necessary for repositories in basalt than for repositories in salt 1500 ft or $153 \mathrm{~m})$. A buffer zone of $500 \mathrm{ft}(153 \mathrm{~m})$ probably would not eliminate any Columbia River basalt flows from consideration for hosting a geologic repository.

MINIMUM VERTICAL EXTENT OF HOST ROCK

CRITERION 10 CFR 60.122 (c) (1) (ii) (a)

The site shall be selected so that to the extent practicable the candidate area contains a host rock and surrounding confining units that provide a geologic framework, such as extensive vertical and lateral continuity, that provides long groundwater residence times and long flow paths prior to entering the accessible environment.

ONWI CRITERION 2.1.2

The thickness of host-rock units at the repository horizon shall be sufficient to accommodate repository workings and to assure that impacts induced by construction of the repository and by waste emplacement will not unacceptably affect repository performance.

PROPOSED CRITERION

The repository rock shall have sufficient vertical extent to preclude breaching of geological containment by repository excavation, drilling, and blasting, or by waste heat production after the wastes are emplaced, or by structural instability of the open excavations.

SCREENING SEECIF ICATION

For salt domes, the minimum vertical extent of salt above the repository shall be approximately $500 \mathrm{ft}(153 \mathrm{~m})$. No quantitative screening 
specification for basalt can be justified at this time due to the lack of information on rock mass thermal and mechanical properties, repository layout and design, and waste heat loading. In absence of a quantitative screening specification, the general criteria above should be applied.

\section{DISCUSSION}

A major factor determining this screening specification for dome salt and basalt is thermal transport behavior. Data obtained for bedded salt indicate that the maximum allowable temperature at the upper and lower boundaries of a salt formation is approximately $120^{\circ} \mathrm{C}$ (Oak Ridge National Laboratory (ORNL), 1973). This temperature is considered to be the limit for precluding major alteration of surrounding rocks containing significant quantities of hydrated minerals. The minimum thickness of a salt bed required to keep boundary temperatures below $120^{\circ} \mathrm{C}$ is $200 \mathrm{ft}(61 \mathrm{~m})$, assuming the repository is centered at mid-thickness within the salt stratum (ORNL, 1973). Assuming that the thermal properties of dome salt are similar to bedded salt, the salt come must be at least $200 \mathrm{ft}(61 \mathrm{~m})$ thick. All of the salt domes in the Gulf Coast that would be considered for a repository are many times thicker than this.

For Columbia Plateau basalt, the flow must be thick enough to ensure that heat generated by the emplaced wastes is adequately dissipated within the basalt so that the basalt and rocks above and below the basalt layer are not adversely affected by unacceptably high heat flow conditions. If heat is not adequately.dissipated, elevated temperatures could lead to thermal fracturing of the basalt. If these fractures are not closed by thermal expansion of the basalt, new groundwater migration pathways within, above, or below the repository could be created. In addition, waste heat loading may induce groundwater flow within the basalt and adjacent rocks due to thermal convection. Each of these conditions would result in an increase in the potential for groundwater migration of radionuclides. Therefore, the host basalt flow-must be thick enough to ensure that the waste heat is adequately dissipated within the basalt flow to make certain that thermal fracturing, thermal-mechanical stresses, and thermally induced groundwater, movement are contained within the basalt flow, and the surrounding hydrologic regime in general is not sufficiently perturbed to increase the potential for radionuclide migration cutside the basalt flow. 
Because hard rock drilling and blasting techniques will be used to excavate the repository, local fracturing of the host rock is expected during construction. Therefore, the host rock must be thick enough to ensure that any fracturing or rock deformation associated with excavation activities are well contained within the host rock unit to minimize the potential for breaching of the containment. In the case of salt domes, as the waste disposal room closes, it may be surrounded by a high deformation zone several tens of feet wide (ORNL, 1973). To ensure that the deformation zone is contained within the salt formation, a minimum of $100 \mathrm{ft}$ of salt above the mining horizon is desired.

The structural stability of the open excavations in basalt will depend upon the extent of fracturing resulting $f$ rom excavation blasting, thermal and mechanical properties of the host rock mass (considering joint frequency and conditions), waste heat loading, size and layout of repository openings, and in situ stresses. The host basalt flow must be thick enough to ensure that any deformation, fracturing, or collapse of the rock mass around the excavations are well contained within the host basalt flow to preclude breaching of the containment through the creation of pathways for groundwater circulation.

Other considerations relative to salt domes include irregularities in the top surface of the dome, structural deformations in the top of the salt plug due to diapiric intrusion, and the overall quality and integrity of the salt near the top of the dome. Irregularities in the top surface may not be accurately detected by widely spaced subsurface exploration. This could result in overestimation of the actual thickness of salt above sections of the repository. Structural deformations and discontinuities are likely to have occurred near the top of the dome due to diapiric intrusion. These could adversely affect the thermal and mechanical properties of the salt near the top of the dome. Finally, the overall quality and integrity of salt near the top may have been affected by dissolutioning as the salt intruded, or by incorporation of brecciated host rock.

Another factor influencing the minimum thickness of a repository in ioasalt is the degree to which the thickness of the flow is known to be constant. Most basalt flows are fairly constant in thickness over short distances. However, local irregularities in the surface on which the basalt flowed could result in local variations in thickness. The minimum thickness 
of the basalt flow should therefore reflect the uncertainty associated with variations in fiow thickness expected over the design area of the rscository.

Based on the information discussed above, $200 \mathrm{ft}$ of salt above he repository may not be conservative. Therefore, for screening purposes, the specification for tinis citterion is that at least $500 \mathrm{ft}(153 \mathrm{~m})$ of salt should be above the repository horizon. A lesser thickness of salt above the repository may be shown to be acceptable by appropriate detailed investigations of the geologic conditions near the top of the salt dome.

The discussion of the factors affecting the minimun thickness of a host basalt flow is of nersssity general. Much data has been obtained regarding the thermal and mechanical properties of intact basalts; however, the actual rock mass properties, which are greatly dependent upon jointing frequency anc conditions, have not been adequately determined by appropriate in situ or large scale tests to justify assigning a quantitative screening specification for this criterion.

It should be noted that about 100 flows were tentatively identified in the Pasco Basin in a deep well, drilled by the standard 0 il company of California, that reached a depth of $3248 \mathrm{~m}(10,650 \mathrm{ft})$ without penetrating the base of the basalt sequence (Atlantic Richfield Hanford Company, 1976). In the Columbia River Plateau, individual flows range in thickness from a few feet to over $200 \mathrm{ft}$ (Golder Associates, Inc., 1977; Camp et al., 1973; Dames and Moore, 1978; Hardy et al., 1973) and average about $16 \mathrm{~m}$ (53 ft) (Camp et al., 1973). One flow, which consists of about $50 \mathrm{~m}$ (164 ft) of dense basalt at $1000 \mathrm{~m}(3280 \mathrm{ft})$ below the Hanford site in the Pasco Basin, is considered to be a prime site for a repository (Hardy et al., 1978).

\section{MINIMUM DEPTH TO REPOSITORY}

CRITERION 10 CFR 60.122 (b)

(2) Potential Aclverse Natural Conditions

(i) There is evidence of processes which have caused extreme bedrock incision since the start of the Quaternary Period. 
The minimun depth to the repository horizon shall be such that credible natural processes acting at the surface will not unacceptably affect the repository performance.

PROPOSED CRITERION

The repository horizon shall be at a depth sufficient to separaie the repository from surficial processes and other credible events that culd result in a hazardous breach of the geological containment.

SCREENING SPECIEICATION

For salt domes, the minimum depth to the repository horizon is estimated to be $1000 \mathrm{ft}(305 \mathrm{~m})$. For Columbia platead basalt, the repository shall be located at an elevation at least $425 \mathrm{ft}(130 \mathrm{~m})$ below the present sea level elevation and at a mirimum depth of $500 \mathrm{ft}(150 \mathrm{~m})$ below the minimum elevation of bedrock overlying the proposec repository site.

\section{DISCUSSION}

The minimum depth required for a repository horizon depends on many factors including glacial, eolian, and fluvial erosion, roof stability, meteorite impact, and man-made explosions.

According to Ledbetter et al. (1975), erosion poses no threat of breaching geologic strata overlying Gulf Coast salt domes. Weathering and eolian erosion are confined to relatively shallow depths. Rates of denudation for the Gulf Coast area are about $5 \mathrm{~cm} / 1000 \mathrm{yr}$. Brunton et al. (1978) suggest that the net fluvial activity throughout the Gulf coast has been depusitional since the end of cretaceous time. However, during periods of glaciation, the lowering of sea level could result in stream channel downcutting. Therefore, the repository should be deeper than the maximum lowering of sea level during the Pleistocene, i.e., $425 \mathrm{ft}$ (130 m) deep (Milliman and Enery, 1968). An additional depth of several hundred feet is desired to protect against 
dissolutioning of the roof and roof instability in the event of deep erosion during periods of lowered sea level.

According to Judson and Ritter (1964), the present rate of denudation in the Columbia River basalts $(4 \mathrm{~cm} / 1000$ yr--measured by monitoring sediment concentrations in the columbia River for a 2-yr period) is lower than any other major drainage basin in the United states. Combined with a regional rate of subsidence of approximately $1 \mathrm{~mm} / \mathrm{yr}$ (Tillson, 1970), which will tend to decrease the rate of denudation with time, the Columbia River basalt region appears to be the optimum region in the United states for minimizing the impact of slow erosion processes on a deep repository. However, although these measured denudation rates provide a means for comparing regional erosion rates, the absolute rate of surface erosion cannot be determined either regionally or locally from these measurenents (Trimble, 1977). Local rates of erosion depend on land use, vegetative cover, slope, relief, and resistance of surficial materials to erosive processes. Moreover, these factors can alter the rate of erosion by more than an order of magnitude within a single drainage basin (Bloom, 1978). Concentrated stream erosion occurs at rates much higher than those interpreted fron regional averages. In addition, future rates of erosion depend on climate and available relief with respect to the base level of erosion (Thornbury, 1957). Thus, erosion rates interpreted regionally or even measured locally over a short period of geologic time should not be extrapolated to determine an acceptable minimum depth for a repository that would not be exhumed by $10 \mathrm{w}$ erosional processes in the long term. It is preferable to determine the minimum depth of a repository by examining the minimum elevation of the base level of erosion expected during the period of time required for geologic containment.

The absolute base level of erosion in the Columbia River basalts is the apparent sea level. The elevation of the apparent sea level at the mouth of the Columbia River is a function of tectonic and isostatic crustal movements and eustatic sea level fluctuations. It is rossible that these factors may combine in" the future to produce an apparent sea level approximately $130 \mathrm{~m}$ below the present sea level. Thus, in order to ensure that the repository will be located below the base level of erosion and consequently will not be exhumed by slow erosion processes in the long term, the criterion for the minimum depth of a repository in the Columbia River basalts should include 
that the maximum elevation of the repository shall be at least $130 \mathrm{~m}$ below the present sea level elevation.

Glacial erosion is not considered in regard to salt domes, since the Gulf Coast area was not subject to Pleistocene glaciation.

Continental glaciation during the Pleistocene epoch covered the northernmost portions of the Columbia River basalts with glacier thicknesses exceeding 1000 ft (Richmond et al., 1965). Such glaciation may recur within the next 10,000 yr (John, 1979). However, highly resistant basalt bedrock with hundreds of meters of relief restricted the flow of glaciers to low velocities and prevented deep erosion. Glacial scouring was restricted to removal of surficial sediments and relatively shallow grooves (tens of meters deep) in bedrock (Flint, 1957). Similarly, future glacial scouring would not adversely affect a repository buried deeper than $150 \mathrm{~m}$ in basalt.

Repeated catastrophic outbursts of extinct proglacial Lake Missoula, formed during Wisconsin glaciation, deeply eroded the Columbia River basalts. Geologic evidence indicates that as many as five outbursts (the most recent outburst occurring less than $13,000 \mathrm{yr}$ ago) randonly enlarged or completely altered previously existing drainage patterns, completely scoured surficial sediments, and eroded channels and basins up to $120 \mathrm{~m}$ deep in the basalt bedrock (Patton and Baker, 1978). The resulting topography, termed the channeled scablands, is found over a large portion of the Columbia River basalts. Because it is possible that this phenomenon could recur during future glaciation and the location and depth of future channels of erosion cannot be predicted, a repository in the Columbia River basalts should be located below the existing bedrock surface at a depth adequate to prevent exhumation if an equivalent catastrophic proglacial lake outburst recurred (i.e., greater than $150 \mathrm{~m}$ ).

A major meteorite impact or the largest man-made explosions would probably penetrate (cause severe brecciation of rock) to a depth no greater than $100 \mathrm{~m}$, although some fractures may extend to a depth 1.5 times that of the penetration depth (Claiborne and Gera, 1977). Lee et al. (1978) report that in basalt a surficial nuclear explosion with an equivalent energy of $100 \mathrm{kt}$ of TWr would penetrate to a depth no greater than $35 \mathrm{~m}$. Moreover, an expression predicting the probability of meteorite impact, developed by Claiborne and Gera (1977), indicates that the probability of a meteorite striking a $1-\mathrm{km}^{2}$ repository area with sufficient energy to penetrate $100 \mathrm{~m}$ 
is approximately $2 \times 10^{-12}$. Therefore, burial deeper than $150 \mathrm{~m}$ in basalt or dome salt would provide adequate protection against these events.

For preliminary screening purposes, the minimum depth to a repository in dame salt is estimated to be $1000 \mathrm{ft}(305 \mathrm{~m})$. Because salt domes consist of a continuous plug of salt from the top of the dome down to the mother ted, it does not matter how shallow the top of the salt dome is. Even if the top of the dome is at the ground surface, the repository can be located at the minimum depth of $1000 \mathrm{ft}$, since the Louann salt mother bed is never shallower than $15,000 \mathrm{ft}$. Therefore, no specification is required for the minimum depth to the top of the salt dane.

For Columbia River basalt, the minimum depth to the repository shall be at least $300 \mathrm{ft}(90 \mathrm{~m})$ below the present sea level and $500 \mathrm{ft}(150 \mathrm{~m})$ below the minimum elevation of bearock overlying the repository site.

\section{MAXIMUM DEPTY TO REPOSITORY}

CRITERION 10 CFR 60.122 SITING

As a minimun, the volume shall be assumed to extend a horizontal distance of $2 \mathrm{~km}$ and a vertical distance from the surface to a depth of $1 \mathrm{~km}$ below the limits of the repository excavation.

ONWI 2.1 CRITERION I. SITE GEOMEFRY

The repository site shall be located in a geologic environment with gecmetry adequate for repository placement.

2.1.2. The thickness of host-rock units at the repository horizon shall be sufficient to accommodate repository workings and to assure that impacts induced by construction of the repository and by waste emplacement will not unacceptably affect repository performance. 
DOMED SALT

\section{Proposed Criterion}

The repository shall be at a depth where the state of stress of the host rock and surrounding rociks does not jeopardize the construction, operation, and physical integrity of the repository.

\section{Screening Specification}

The maximum depth to $t l$ e top of the salt dome shall be approximately 2500 ft $(762 \mathrm{~m})$.

\section{Discussion}

The maximum depth to the repository will be governed primarily by rheological and mechanical properties of the dome salt. The rate of plastic flow of salt exhibits pronounced acceleration as pressure increases with depth. At large depths, salt pillars between mined openings cannot support the weight of overlying rock strata, and mined openings tend to close.

The rate of closure is affected not only by the properties of the salt but also by the repository layout and design. A lower extraction ratio (ratio of mined area to total area of a repository in plan view) typically leads to a lower closure rate because more salt is left in the ground to support the overlying strata, and pillar stresses are lower (GEI, 1979). Closure rate can also be controlled by support techniques such as bolting and bracing (GEI, 1979). Therefore, proper design of excavated vaults and proper spacing of passageways can minimize stresses, thus allowing construction of a repository at greater depths. Acceptable rates of closure will depend upon the length of time the repository rooms are required to remain open and stable.

Historical experience in potash and salt mines indicates that at depths greater than about $3000 \mathrm{ft}(91 \mathrm{~m})$ the rate of closure in salt becomes excessive and hazardous (Brunton et al., 1979).

Another factor that may be important at depths greater than $2500 \mathrm{ft}$ $(762 \mathrm{~m})$ is the geothermal gradient. Fischer and Judson (1975) report geothermal gradients of up to $2.7^{\circ} \mathrm{F} / 100 \mathrm{ft}$ in the internal salt dome region 
of the Gulf Coast. At greater depths the increased temperature could conceivably affect the rock-waste interactions and mechanical behavior of the rocks.

BASALT

\section{Proposed Criterion}

The repository shall be at a depth where the hydrologic and structural properties of the basalt are no jeopardy to the physical integrity of the reposi tory.

\section{Screening Specification}

The maximum depth to the top of the repository shall be approximately 4000 ft $(1200 \mathrm{~m})$.

\section{Discussion}

The three factors that must be considered in determining a maximum depth for a repository in basalt are hydraulic head conditions at depth and geothermal gradient.

The water table in near-surface sediments and rocks in the Columbia Basin area slopes towards the Columbia River in general. Away from the river, the piezonetric heads at great depths are below the water table; near the river, heads are above the water table and the mean stage of the river.

Deju and Fecht (1979) state that vertical flow in deep basalts is generally from the upper to lower zones. However, the regional system of horizontal or vertical groundwater movement in deep basalts is not well understood. Therefore, extensive investigations will be required before a decision can be reached as to whether or not the hydrology at great depths is important in choosing a maximum depth.

The groundwater temperature in the Columbia Basin ranges from $19^{\circ} \mathrm{C}$ at the surface to $75^{\circ} \mathrm{C}$ at a depth of $1500 \mathrm{~m}$ (Benson, 1978). This geothermal gradient probably would have little effect on a repository in basalt; however, further investigations are needed in any proposed repository site. 
A repository shall not be located where there is a concentration of earthquake activity relative to the regional distribution of earthquakes or there are indications that earthquake activity may be concentrated in the future based on either the distribution and frequency of occurrence of earthquakes or the correlation of earthquakes with tectonic processes and features.

ONWI CRITERION 2.2.1

The repository site shall be located so that ground motion associated with the maximum credible earthquake will not have unacceptable adverse impact on repository perfol:mance.

PROPOSED CRITERION

The repository shall be located at a site where ground motions associated with predicted seismic activity will not have unacceptable adverse impact on the safe operation or the containment capability of the repository.

\section{SCREENING SPECIFICATION}

The Gulf Coast and Columbia Plateau areas are characterized by low to moderate seismicity and the maximum expected seismic shaking is not likely to adversely affect a repository. Therefore, no seismicity screening specification need be applied.

\section{DISCUSSION}

The adverse effects of seismic ground motions on a geologic repository would be limited primarily to surface waste handling facilities during their relatively short operational lifespan. Experience in mines and tunnels indicates that only minor surficial damages are caused by seismic shaking, and 
seismic resistant design of underground openings is not a problen (Rosen, 1976; MRC/NAS, 1978). More significant damages have occurred at tunnel and mine shaft portals, and, in scme cases, where the earthquake-generating fault actually intersected the underground opening. After the repository has been backfilled and the surface facilities have been decommissioned, seismic ground motion poses no significant hazard to geologic containment of radioactive wastes. Surface facilities and mine shaft openings would experience more severe ground motion than the underground workings of a repository, and would have to comply with seismic criteria similar to those developed for nuclear power plants. In areas such as California and Puget Sound, Washington, nuclear power plants have been designed to withstand relatively high seismicity.

The seismic risk zone map of Algermissen (1969) indicates that all of the onshore salt domes in the Gulf coast region are in either zone 0 , characterized by no damage, or zone 1, characterized by minor damage from ground motions associated with modified Mercalli intensities of $V$ and VI. Since seismic intensity will be even lower underground at the repository level, the maximum expected seismic shaking throughout the Gulf coast area is not likely to adversely affect a repository constructed in any salt dome.

The Columbia River Plateau is characterized by moderate seismicity. The highest modified Mercalli intensity observed near the epicenters of historic earthquakes is VII, and the largest instrumentally recorded earthquake has been 5.75 on the Richter magnitude scale (Atlantic Richfield Hanford Company, 1976). Epicenters of historic Columbia River Plateau earthquakes form a diffuse pattern, with no unambiguous correlation to specific geologic structures. The larger and mora frequent earthquakes of the Puget sound region have produced modifizd Mercalli intensities of IV or less on the Columbia River Plateau (Atlantic Richfield Hanford Company, 1976).

Historic smicity indicates that any site for a basalt repository on the Columbia River plateau would be acceptable with regard to seismic ground motion. The potential hazard of ground motion is primarily on the safe operation of surface waste handling facilities, which can be designed to be safe during the maximum credible e.thquake for a Columbia River basalt site. Based on the generally low-to-moderate historic seismicity of the Gulf Coast and Coiumbia plateau, the minimum expected seismic shaking is not likely to adversely affect a repository in those areas. Therefore, no screening specification need be applied. 
In order to adequately predict seismicity at any proposed repository site, it is necessary to consider the historical seismic record and the state of stress in the region of interest.

\section{TECTONIC SETTING}

CRITERION 10 CFR 60.122

(2) Potential Adverse Natural Conditions--Geologic and Tectonic

(iii) There is evidence of processes which may result in structural deformation such as uplift, diapirism, subsidence, folding, faulting or fracture zones.

(vii) There is evidence of intrusive igneous activity since the start of the Quaternary Period.

ONWI CRITERTON II. TECTONIC ENVIRONMENT

The repository site shall be located such that credible tectonic events can be shown to cause no unacceptable reduction in repository performance.

2.2.4. The repository site shall be locateu so that long-term, continuing uplift or subsidence rates can be shown to fave no adverse impact on the repository.

2.2.5. The repository site shall be located so that its tectonic enviroment can be evaluated to identify tectonic elements and their impact on repository performance with a high degree of confidence. Fotentially hazardous geologic elements, especially faults and volcanoes that have ieen active during the Quaternary Period, must be investigated in detail sufficient to assess their potential effects on repository performance. 
The repository shall be located in an area where the rate and amount of predictable long-term uplift and subsidence will not pose a threat to repository containment.

DOHED SALT

Screening Specification 1

The repository shall be located in a salt dome in the Gulf Interior subprovince unless detailed investigations show that subsidence in the Gulf Coastal subprovince will not cause unacceptable diapiric movements in a candidate coastal salt dome.

\section{Screening Specification 2}

The repository shall be located in a salt dome which bears no stratigraphic or geomorphic evidence of uplift due to diapirism of overlying formations since the beginning of the Quaternary Period (2 M.Y.).

For the purposes of this report, diapirism is defined as the upward intrusion of a mass of deformable rock salt into overlying strata, resulting in the formation of structural anticlines or salt domes. This process is due to shearing forces created by the density contrast between the salt and overlying sediments. The potential effects of diapirism on a salt dome repository are discuss d in detail by GEI (1980c).

\section{Discussion}

The screening specifications for salt domes will be divided into two parts--a discussion of epeirogenic and isostatic uplift and subsidence as they relate to diapiric activity in specific salt dome areas of the U.S., and a separate section defining diapirism and associated movements along with a discussion on how geomorphic and stratigraphic information may predict diapiric movement. 
The Gulf Coastal region appears to be tectonically stable with only gentle epeirogenic and isostatic movements since the Late Triassic (160 million yr ago). The last major tectonic activity was the Late Triassic block faulting which formed the Gulf Coast Basin (Law Engineering and Testing Company, 1978): At present, only minor elevation fluctuations are occurring, generally characterized as a slow southward isostatic down-warping of the Gulf Coast subprovince sediments and a complementary rise in elevation toward the northern interior subprovince.

Studies indicate that the Gulf Interior subprovince salt domes are generally inactive while many Gulf Coast salt dames are still moving (Anderson et al., 1973; Ledbetter et al., 1975; Martinez et al., 1975, 1976, 1977; Netherland, Sewell \& Assoc., Inc., 1976; Law Engineering Testing Company, 1978; Bechtel National, Inc., 1978).

During the Jurassic Period (130 M.Y.) vast thicknesses of evaporites consisting mainly of halite were deposited in the protomgulf depositional basin. This formation of bedded salt, with some carbonates and sulfates, is known as the Louann Salt, the somcalled "mother" formation of the Gulf Coast salt domes. The maximum development in the Gulf Interior subprovince occurred from the Cretaceous to Eocene time (Bechtel National, Inc., 1978). Stratigraphic and structural data indicate that salt domes in the North Louisiana interior subprovince ceased movement during the Late Oligocene (30 M.Y.) where others in the Northwest Texas Basin ceased during the Lower Eocene-Upper Paleocene Epochs (55 M.Y.) (Martinez et al., 1975, 1976, 1977).

The average uplift over salt domes due to diapiric intrusion in the Northeast Texas Basin has been estimated to be $0.006 \mathrm{~mm} / \mathrm{yr}$ during the past 50 million years or 5 feet in 250,000 years (Netherland, Sewell and Assoc., Inc., 1976). Therefore, Gulf Interior salt domes are generally considered inactive.

In contrast, salt domes of the Gulf Coast subprovince are reported to have disturbed Pleistocene (<2 M.Y.) strata (Ledbetter et al., 1975), indicating that coastal salt dames have been more recently active than those in the interior. This assumption is in agreement with the present erosional and depositional environment of the two subprovinces. Sedimentation in the interior basins ceased long ago and now denudation and erosion is occurring. Therefore, the differential loading required to induce diapirism is being removed, suggesting that the growth of interior salt domes has halted 
(Ledbetter et al., 1975): whereas, coastal domes are in areas of active sedimentation and may therefore still be active.

To ensure the stability of candidate salt domes in either The Gulf coast or Gulf Interior subprovince, thorough investigations of local vertical movenents are required. The investigations may include stratigraphic and geomorphic analysis, leveling, and microseismic and tiltmeter studies.

Estimates of the movement or activity of salt domes can be obtained by careful evaluation of existing stratigraphic and geomorphic evidence. Information may be obtainable from existing boreholes, seismic reflection or refraction surveys, resistivity profiles, age dating tests, etc. Structural cross-sections through the salt dome and surrounding basin sediments will indicate which beds have been subject to deformation. By estimating the age of the youngest beds disturbed by intrusion of the salt, it is possible to determine when diapirism ceased. Mapping surficial deposits may show evidence of structural offset of Pleistocene terraces or other Quaternary deposits, which could also remove a salt dome from further consideration.

Geomorphic analysis may also provide indications of the activity of salt domes. Basic drainage patterns, such as dendritic and trellis, are controlled to a certain extent by regional structure. Deviations from the regional pattern may suggest structural or topographic anomalies (Howard, 1967). These ancmalies may show up because drainage patterns are sensitive to changes in gradient and thus are good indicators of local movement, such as uplift due to a salt dome. Since adjustment of drainage patterns to changes in gradient occur relatively rapidly in geologic time, drainage anomalies may reveal recent tectonic or diapiric activity (Ledbetter et al., 1975). Some typical drainage anomalies associated with salt domes are a radial-annular expression within a dendritic pattern, local stream meandering, and braiding (Boward, 1967). Therefore, the most favorable domes will not exhibit a drainage pattern anomaly or will indicate only minor movement.

The impact of tectonic activity, either from igneous or diapiric intrusion, must be thoroughly investigated for the presence of associated faulting and fractures. The presence of associated structural deformations may also be important in the interaction between the groundwater regime and the repository. 


\section{Screening Specification}

A repository site is acceptable if the amount of long-term uplift cannot reasonably be expected to exceed the initial repository depth within the time span considered necessary for geologic containment.

\section{Discussion}

Areas that experience relatively rapid rates of uplift will undergo accelerated erosion, which could possibly breach geologic barriers to radioactive waste migration. The potential effects of erosion and tectonic activity on waste repositories are discussed in detail by GEI (1980a, d). Large differential vertical movements, such as those caused by folding, could adversely affect the hydrologic integrity of the repository by creating new fractures in the host rock. Two different types of data have been used to assess vertical tectonic movements--(1) geodetic measurements and (2) geologic and geomorphic evidence. These two sources generally yield very different estimates of vertical deformation rates, a disparity which is addressed in detail by GEI (1980a).

Releveling surveys of the Columbia River Plateau indicate a regional trend of subsidence of approximately $1 \mathrm{~mm} / \mathrm{yr}$ (Tillson, 1970). Local areas within the plateau had relative subsidence rates of up to $4 \mathrm{~mm} / \mathrm{yr}$ and relative uplift rates up to $3 \mathrm{~mm} / \mathrm{yr}$, although these local trends did not correlate with known geologic structures. The Pasco Basin area is subsiding at a rate of approximately $1 \mathrm{~nm} / \mathrm{yr}$.

The rates of movement observed on the Columbia Plateau are typical of other tectonically stable areas of the world. The rolative rates of movement detected by geodetic releveling are on the order of several nmar $/ \mathrm{yr}$ in tectonically stable regions, and up to several $\mathrm{cm} / \mathrm{yr}$ along major active tectonic boundaries (Brown and Oliver, 1976; Castle et al., 1976; Mescherikov, 1967). The degree to which releveling data are affected by systematic errors is not well understood. Vertical movement rates determined from long-term monitoring of tide gages are in general agreement with leveling data, a fact that lends credibility to leveling data. The magnitude of present movement 
rates determined from leveling data appear reasonable, but they may not be indicative of long-term rates of vertical deformation. Rapid vertical movements of large parts of the Columbia plateau may also occur as the result of glacial loading and unloading. The potential effects of these stresses will be evaluated.

Vertical tectonic movement rates over larger time spans have been determined fram geologic evidence, and the resulting rates are consistently one or two orders of magnitude less than rates inferred from geodetic data. The Rocky Mountains have uplifted 1500 to $3000 \mathrm{~m}$ in the past $15 \mathrm{million}$ years, an average rate of 0.1 to $0.2 \mathrm{~mm} / \mathrm{yr}$ (Press and siever, 1974). Geologic evidence indicates that the predominant recent tectonic deformation of the Columbia River Plateau has been the development of several anticlinal structures exhibiting east-west trending. Several of these structures are in the Hanford Reservation, and have a maximum structural relief of approximately $1000 \mathrm{~m}$ (Piper, 1975). The deformation began approximately 10 million years ago, and if continuing, would imply an average deformation rate of $10 \mathrm{~m} / 100,000$ yr $(0.1 \mathrm{~mm} / \mathrm{yr}$ ) (Brown, 1969). Deformation at such a slow rate would not pose a threat to the integrity of a geologic repository in the Pasco Basin basalts.

In conclusion, geologic and geodetic evidence indicates that repository sites in the Columbia River Plateau and particularly in the Pasco Basin would be acceptable with respect to vertical tectonic movement criteria, pending further detailed investigation. A general trend of regional subsidence indicated by geodetic surveys would not adversely affect a repository. Recent folding in the Columbia River Plateau is occurring at a slow enough rate that only minor net movements would be anticipated within the time spans considered for geologic containment of radioactive wastes.

STRUCTURAL SETPING

CRITERION 10 CFR 60.122

(2) Potential Adverse Natural Conditions - Geologic and Tectonic 
(iii) There is evidence of processes which may result in structural deformation such as uplift, diapirism, subsidence, folding, faulting or fracture zones.

(iv) The geologic repository operations area lies within the near field of a fault that has been active since the start of the Quaternary Period.

(v) There is a fault or fracture zone, irrespective of age of last movement, which has a horizontal extent of more than a few hundreds of meters.

ONWI 2.2 CRITERION II. TECTONIC ENVIRONMENT

The repository site shall be located such that credible tectonic events can be shown to cause no unacceptable reduction in repcsitory performance.

2.2.2. The repository site shall be located so that quaternary faults can be identified and shown to have no unacceptable adverse impact $c:$ reposi tory performance.

\section{ONWI 2.5 CRTTERION V. GEOIOGIC CHARACTERISTICS}

The repository site shall have geologic characteristics compatible with waste isolation.

2.5.1. The repository site shall be located so that the stratigraphic setting can be sufficiently defined to permit modeling as part of the repository system.

DOMED SALT

\section{Proposed Criterion}

Faults and other structural discontinuities at or tear the repository site shall not jeopardize the construction, operations, or geological containment of the repository. 
The repository shall be located in an area that meets the following conditions: no faults that have moved during the Quaternary Period within the control zone, $*$ and no faults that provide a permeable pathway for movement of water through the repository to surrounding aquifers within the control zone.

\section{Discussion}

When one or more large faults related to tectonic forces other than diapirism occur within the repository control zone a detailed history of movement must be evaluated. The repository may be located near such a fault provided it can be demonstrated that the fault has not moved during the Quaternary Period, and that the existence of the nonactive fault does not in any way compromise the containment of waste or repository construction and oper ation.

Many minor faults, folds, and structural discontinuities, such as fractures, shears, joints, are found associated with salt domes due to the forceful intrusion of the salt into the overlying sediments during diapirism. These discontinuities may result in an increase in secondary permeability and the potential for groundwater movement in and around the dome for a short period following intrusion. However, after dames have ceased to move, structural discontinuities associated with diapiric movement may have little or no effect on groundwater circulation because of the plastic, healing behavior of salt with time.

The fact that structural discontinuities are expected in and around all salt domes should not be sufficient cause to preclude any dome from further consideration as a repository site. However, the repository should not be

*Control zone: the area surrounding the geologic repository operations area to be under the jurisdiction and control of the Department of Energy to ensure that natural or human activities do not compromise the ability of the site to meet repository performance objectives. The minimum extent of the control zone shall be a horizontal distance of $2 \mathrm{~km}$ and a vertical depth of $1 \mathrm{~km}$ below the limits of the repository excavation (OFR, 1980). 
located at a site where any faults or structural discontinuities in a salt dome or buffer zone are known to provide permeable pathways to overlying aquifers, or where structural discontinuities can jeopardize construction, operation, or geological containment. In addition, the effects of previous withdrawal of subsurface fluids and minerals shall not have caused unacceptable adverse impacts on the permeability and potential for movement along structural discontinuities.

Detailed investigations will be required for salt domes to be considered as potential repository sites. Among these investigations should be analyses of linear topographic expressions using aerial photos and remote sensing images, spring and groundwater irregularities associated with faulting, geophysical methods, such as seismic surveys, and finally an investigation of borehole geophysical logs to determine changes in subsurface stratigraphy.

\section{BASALT}

\section{Proposed Criterion}

Faults or any structural discontinuities (joints) in or near the repository site should not jeopardize the construction, operation, or long-term geologic containment of the repository.

\section{Screening Specification}

The repository site shall meet the following conditions to warrant further study: no active Quaternary faults within the repository control zone or close enough that movement along the fault could compromise hydrologic or geologic stability; no existing fauls, active or inactive, that could provide unacceptable hydrologic communication between the repository and adjacent aquifers.

\section{Discussion}

Faults that intersect a repository represent potential pathways for the migration of groundwater through the repository. Another hazard posed by faults is the potential for displacement, which could disturb geologic and 
hydrologic barriers to waste migration. Faulted and fractured rock also poses engineering problems during excavation and construction of underground openings. Although mining technology has been developed to handle poor rock conditions in highly fractured and faulted rock, such areas should be excluded during the initial screening process to minimize the potential for jeopardizing construction operations. Identification of fauits and evaluation of their displacement history and hydrologic characteristic's is necessary for effective screening of sites. These studies are more critical for faulis closer to the potential repository site.

Various methods have been developed to measure displacement along faults. One way is the actual measurement of displacement using known linear features, such as the intersection of a dike or the offset of a known sedimentary sequence. These measurements can be done on a surface expression of a fault or, in some cases, by differences in the stratigraphic sequences in bore holes.

Another method that may be used as an indication of movement along faults is the presence of polished striated surfaces known as slickensides. All such striations were originally thought to be caused by abrasion during fault movement (Billings, 1972); however, in some cases the striations are due to parallel growth of elongate crystals (Hobbs et al., 1976). Studies by Durney and Ramsey (1973) reveal that the orientation of fibrous crystal growth is parallel to the direction of fault displacement. Fault drag or deformation of planar features adjacent to faults can be another indicator of the sense of displacement on a fault.

The age of a fault or fauit zone may be determined by several methods. Based on structural relationships, it is possible to determine if a particular dated material predated, postdated, or coincided with fault movement. Other possible methods of dating a Eault include radiometric; residual soil, and weathering profiles (Machette, 1978); paleontology, palynology, palecomagnetism, and fluid inclusions (Peck, 1980); and glass hydration (Friedman and Long, 1976). More detailed information on state-of-art methods for determining fault movement age has been provided by GEI (1980a) . Most of the Columbia River Plateau is characterized by a low density of faults, although higher fault densities are found along the southern margin of the Plateau in oregon. In the vicinity of the Hanford Reservation, major faults are associated with anticlinal ridges. Deformation of these structures 
commenced approximately 10 million years ago, but it is not known if deformation continues at present (Brown, 1978). Several of the faults associated with anticlines near Hanford have apparently had no displacement younger than 10,000 to 40,000 years, based on carbon-14 dating of undeformed materials overlying the faults (Piper, 1975). Microseismic studies in the Pasco Basin indicate that no unambiguous correlation can be drawn between epicenter distributions and fault locations (Atlantic Richfield Hanford Company, 1976). One exception may be the Blue Mountain fault near Walla Walla. The epicenters of several felt earthquakes are located along a trend coinciding with the fault. Geodolite trilateration surveys across some of the faulted anticlines in the vicinty of Hanford reveal no perceptible horizontal movements (Prescott and Savage, 1973).

Acceptance of potential repository sites in or near these fauj ted anticlines would require further studies to better define the recent history of deformation and faulting. If such a site is deemed acceptable with regard to potential fault displacement, the hydrologic implications of the fault must then be investigated.

The repository shall be located in a section of a basalt flow meeting the following joint conditions: joints shall be tight such that they would not provide open pathways for the movement of water and would not represent surfaces of easy parting that would cause major difficulties during construction; joint surfaces shall show no evidence of recent weathering that could be attributable to groundwater circulating through the basalt flow; and joints should be of such spacing, extent, or orientation that joint intersections do not provide a continuous pathway for the movenent of groundwater or result in potentially unstable blocks of rock that would cause major construction difficulties.

Dames and Moore (1978) briefly discuss the history of formation and geometry of jointing in Columbia Plateau basalts. The tops and bottoms of flows generally are characterized by chaotic or hackly jointing. The flow centers (colonnade) generally consist of massive rock with distinctly developed columnar jointing. Joints are generally tightly closed at depth within the thick flow sequence in the central Columbia River Plateau (Dames and Moore, 1978). A more detailed summary of joint formation and vertical distribution in basalts is presented by willard Owens Assoc., Inc.. (1979). 
Jointing conditions, however, do not necessarily remain constant when flows are traced laterally for tens of kiloneters. Jointing reflects the cooling history of the flow which changes not only with the thickness of the flow, but also with the distance from the vent, the nature of the surface covered, and whether the basalt solidified from a ponded, motionless fluid or continued to creep during the period of crystallization. Therefore, jointing conditions change laterally within a given basalt flow.

Once the flow has solidified, the top surface can undergo weathering winile it is exposed to the atmosphere (Dames and Moore, 1978). Many basalts weather to form secondary minerals, such as nontronite and beidellite which are both clays of the montmorillonite group (Deju, 1977). Deju (1977) indicates that joints and fractures deep in the columbia River plateau basalts are filled with these montmorillonite clays.

The weathering and infilling of joints in basalts affect the engineering properties of basalts in several ways. Joints infilled with clay may be relatively impermeable, as indicated by preliminary hydrologic test data (Agapi to et al., 1977). The Atlantic Richfield Hanford Company (1976) states that some thick Columbia plateau basalt flows (up to $50 \mathrm{~m}$ thick) are quite impervious, since nearly all joints and fractures are filled with secondary clays. Therefore, these thick basalts with clay-filled joints may represent hydrologically isolated units, an important factor in minimizing the potential for radionuclide migration.

The engineering properties of a jointed rock mass depend not only on the characteristics of the intact rock material, but also upon the engineering properties of the joints. Following is a brief discussion of the general effects of jointing on several of the rock mass properties important in the site selection process for a repository in basalt.

Rock mass strength characteristics are used in conjunction with the stress field predictions of analytical models to predict the extent of failure zones surrounding underground excavations. Rock mass strength characteristics of the basalt flow will affect excavation stability (Golder Associates, Inc., 1977).

Dames and Moore (1978) discussed the general effects of joints on two important design parameters-Young's modulus and unconfined compressive strength. In each case, the rock-mass values typically are much smaller than the intact rock values. The rock-mass values may usually be obtained from the 
intact rock value by multiplying by an appropriate reduction factor. Because the reduction factor depends on such factors as joint orientation, spacing, and infilling, considerable judgment is required in selecting a suitable reduction factor. Although rock-mass properties (and reduction factors) may be determined directly from large-scale field tests, no such deep in situ experiments have been performed in the Columbia Plateau basalts.

Based on uniaxial compressive strength tests on samples with closed joints that were intact after coring, Agapito et al. (1977) indicated that joints reduced the cohesion and the angle of internal friction of basalt. Because many other joints opened and separated during the drilling process, Agapito et al. (1977) assumed that these joints would have been even weaker than those tested.

Weathering and infilling of joints in basalts generally decrease the compressive strength and Young's modulus of basaltic rocks. Dames and Moore (1978) report that the compressive strength of basalt from Michigan ranges from 37,400 to 52,000 psi in the dense unaltered state. Strengths decreased to 11,300 psi for altered basalt, and decreased to $2470 \mathrm{psi}$ for heavily altered and zeolitized basalt. Young's modulus, based on dynamic testing, ranged from 8.93 to $13.9 \times 10^{6}$ psi in the unaltered concition to $0.91 \times 10^{6}$ psi- for zeolitized basalt (Dames and Moore, 1978).

The thermal properties of a rock mass are influenced by the presence of joints, particularly if the joints are open or filled with a material of different thermal properties than the host rock (Agapito et al., 1977). Thermal conductivities are influenced by the spacing, orientation, and surface condition of the joints. An open joint (air-filled) would appear to be a good insulator, with most of the heat flow from one side of the joint to the other through points of contact of the joint surfaces. As the thermal conductivity of air is about 0.58 of the thermal conductivity of rock, a thin layer of air contained in a joint can have a significant influence on the rock mass thermal properties. Where few contact points are present between the joint surfaces, the thermal conductivity of an open joint is close to that of air; therefore, the thermal conductivity of the rock mass will be reduced.

The thermal conductivity of water is about $17 \%$ of the thermal conductivity of basalt (Birch et al., 1961), or about 33 times the conductivity of air. Therefore, joints filled with water will conduct heat away from the repository much more rapidly than those filled with air, but not 
as rapidly as tight, clean joints or intact rock. Circulation of water in joint systems may develop into convection which is a more efficient mode of heat transfer than simple conduction. The heating of water-filled joints may also tend to increase joint openings and in situ rock mass stresses, and may induce groundwater movement. Such effects are not well understood and should be investigated.

It is anticipated that the joints in the Grande Ronde basalt (primary candidate basalt group for hosting a repository) will be tightly closed (Agapito et al., 1977). Therefore, the influence of jointing on rock mass thermal conductivity is likely to be low. However, this will have to be demonstrated by large scale tests on undisturbed jointed rock masses.

Although clay-filled joints enhance the hydrologic characteristics of a basalt flow, they diminish several engineering properties of basalt important to repository construction and geologic containment. The weathering and infilling of joints in basalts generally decrease the compressive strength and Young's modulus of basaltic rock. The shear strength of fresh joint surfaces may be high when clean and unweathered but may undergo a dramatic strength drop when weathered or infilled (Dames and Moore, 1978).

The effects of elevated temperatures and groundwater on the engineering properties of clay-filled joints is not well known and will have to be investigated to properly evaluate the rock mass properties of basalt.

Thus, the rock mass properties of basalt--especially compressive strength, Young's modulus, and thermal conductivity-will be dominated by the joint properties. Because the actual effect of joints on these rock mass properties has not been adequately studied with large-scale in situ tests in Columbia Plateau basalts, quantitative screening specifications are difficult to assign to the criterion regarding jointing. 
(1) Potentially Adverse Human Activities

(ii) There is or has been drilling for whatever purpose, except holes drilled for investigations of the geologic repository, to depths below the lower limit of the accessible enviroment.

(v) There is reasonable potential that failure of human-made impoundments could cause flooding of the geological repository operations area prior to Ȧeconuissioning.

(vi) Existing topographic, geomorphic, stratigraphic, hydrogeo]ægic, and climatological characteristics suggest a reasonable potential for construction of large-scale impoundments which may affect the regional groundwater flow system.

(vii) There is indication of present or reasonably anticipatible human activities that ran significantly affect the hydrogeologic framework such as groundwater withdrawals, subsurface injection of fluids, underground pumped storage facilities or underground military activities.

(3) Potentially Adverse Natural Conaitions--Hyảrologic

(i) There is, based on a paleohydrologic evaluation, reasonable potential for significant changes in nydraulic gradients, average pore velocitìes, storativities, permeabilities and natural discharge.

(ii) The geological repository operations area, or any part therec", is within the 100 year floodplain.

(iii) Based on evaluation of the existing topograyic, geomorphic, stratigraphic, hydrogeologic, clinatologic characteristics, and geochemical properties of the rock units, there is reasonable potential for natural phencmena such as 
landslides, subsidence, or volcanic activity to create large scale impoundments that may affect the regional groundwater flow system.

ONWI 2.3 CRITERION III. SUBSURFACE HYDROLOGY AND GEOCHEMISTRY

The repository site shall have subsurface hydrologic and geochemical characteristics compatible with waste isolation.

2.3.1. The repository site shall be located so that the hydrological and geochemical regime will prevent radionuclides from leaving the repository and being transported to the biosphere in amounts or levels above those specified.

2.3.2. The repository site shall be located so that the hydrological regime allows construction of repository shafts and maintenance of shaft liners and seals by state-of-the-art means.

2.3.3. The repository site shall be located so that the subsurface rock dissolution which is occurring, or is likely to occur, can be shown to have no unacceptable adverse impact on the performance of the repository.

ONWI 2.4 CRITERION IV. SURFACE HYDROLOGY

The repository site shall be located so that the surficial hydrological system, both during anticipated climatic cycles and during extreme natural phenomena, will not cause unacceptable adverse impact on repository per formance.

2.4.1. The repository shall be located so that nearby surface water bodies, embankments, streams, floodplains, runoff or drainage under present or future climatological conditions can be shown to present no unacceptable adverse impact on repository performance. 
(1) Potentially Adverse Human Activities

(ii) There is or has been drilling for whatever purpose, except holes drilled for investigations of the geologic repository, to depths below the lower limit of the accessible environment.

(v) There is reasonable potential that failure of human-made impoundments could cause flooding of the geological repository operations area prior to decommissioning.

(vi) Existing topographic, geomorphic, stratigraphic, hydrogeologic, and climatological characteristics suggest a reasonable potential for construction of large-scale impoundments which may affect the regional groundwater flow system.

(vii) There is indication of present or reasonably anticipatible human activities that can significantly affect the hydrogeologic framework such as groundwater withdrawals, subsurface injection of fluids, underground pumped storage facilities or underground military activities.

(3) Potentially Adverse Natural Conditions--Hydrologic

(i) There is, based on a paleohydrologic evaluation, reasonable potential for significant changes in hydrauìic gradients, average pore velocities, storativities, permeabilities and natural discharge.

(ii) The geological repository operations area, or any part thereof, is within the 100 year floodplain.

(iii) Based on evaluation of the existing topographic, geomorphic, stratigraphic, hydrogeologic, climatologic characteristics, and geochemical properties of the rock units, there is reasonable potential for natural phenomena such as 
landslides, subsidence, or volcanic activity to create large scale impoundments that may affect the regional groundwater flow system.

ONWI 2.3 CRITERION III. SUBSURFACE HYDROLOGY AND GEOCHEMISTRY

The repository site shall have subsurface hydrologic and geochemical characteristics compatible with waste isolation.

2.3.1. The repository site shall be located so that the hydrological and geochemical regime will prevent radionuclides from leaving the repository and being transported to the biosphere in amounts or levels above those specified.

2.3.2. The repository site shall be located so that the hydrological regime allows construction $:$ sepository shafts and maintenance of shaft liners and seals by state-of-the-art means.

2.3.3. The repnsitcry site shall be located so that the subsurface rock dissolution which is occurring, or is likely to occur, can be shown to have no unacceptable adverse impact on the performance of the repository.

ONWI 2.4 CRITERION IV. SURFACE HYDROLOGY

The repository site shall be located so that the surficial hydrological system, both during anticipated climatic cycles and during extreme natural phenomena, will not cause unacceptable adverse impact on repository per formance.

2.4.1. The repository shall be located so that nearby surface water bodies, embankments, streans, floodplains, runoff or drainage under present or future climatological conditions can be shown to present no unacceptable adverse impact on repository performance. 


\section{Proposed Criterion}

The repository shall be located in a salt dome that is hydrologically stable or where dissolution of salt can be shown to have no unacceptable adverse impact on the performance of the repository for the required period of containment.

\section{Discussion}

Subsurface instability in salt domes occurs wherever water, unsaturated with respect to salt, flows in contact with the salt. This salt dissolution could lead to a breach in containment by creating solution channels directly to the waste, or by creating solution caverns which could lead to structural instability, roof collapse, or creation of permeable fractures around the repository.

The salt domes that are most susceptible to dissolutioning are those that have intruded fresh water aquifers, and which lack an aquitard, leading to significant groundwater flow. Conditions that may increase the possibility of dissolutioning include surface lakes over salt domes, boreholes, and solution mining activity.

A thorough understanding of local geologic and hydrological conditions around the salt dane is required to permit meaningful evaluation of the hydrologic stability. Surface water bodies with anomalously high concentrations of salt are generally referred to as "surface salines." They occur as salty lakes, salt-water springs, salt marshes, and saline creeks. Sone may precipitate or dry up, forming "salt prairies" or "salt licks." The presence of these saline bodies may indicate salt dissolutioning from salt domes near the surface or from upward flow of water under artesian conditions. However, because the detailed patterns of groundwater movement around most salt domes are not known, the presence of salt at the surface is not necessarily indicative of hydrologic instability. Some other explanations include the leaching of saline water from connate water in uplifted strata above or adjacent to the salt dome (Anderson et al., 1973), or leakage from 
existing or abandoned solution mines (Netherland, Sewell \& Assoc., Inc., 1976). Anderson et al. (1973) noted that the development of sirface salines over salt domes in north Louisiana is independent of the thickness of relatively impermeable caprock and the depth of the domes. They concluded that this information argues against the derivation of surface salines fram dissolution of the top of the salt mass and therefore may not necessarily 1. dicate hydrologis inst=Lizity.

Conversely, the absence of surface saline does not necessarily indicate hydrologic stability. Artesian conditions may not exist to raise saline water to the surface, or the saline waters may be absorbed by a permeable sand aquifer before reaching the surface (Martinez et al., 1976). Therefore, the presence or absence of surface salines may, in some instances, provide an indication of hydrologic stability of a salt dome, but should not be used as a criterion for rejecting or accepting salt domes.

Another phenamenon which may be important in detecting subsurface instability of salt domes is referred to as a "saline plume." Such plumes consist of anomalously high concentrations of sait in groundwater in the aquifers above or adjacent to salt domes. They have been detected in the vicinity of many domes through electric resistivity logging and water sampling in borings and wells.

The presence of saline plumes may inaicate dissolutioning of salt domes. Water that is unsaturated with respect to salt and is flowing through aquifers pierced by a salt dome can dissolve the salt if the dome is not protected by an impervious cap of gypsum, anhydrite, shale, or clay. The saline water is then carried down gradient through the aquifer or upward through porous sediments or fractures to form saline plumes (Netherland, Sewell \& Assoc., Inc., 1976). Other explanations have been offered for the existence of saline plumes that are not related to dissolutioning. For example, connate brines from deeper aquifers may move upward along paths created by diapiric intrusion and discharge of connate brine and dissolved salt to overlying aquifers (Martinez et al., 1976; Smith, 1977). In such instances, the percentage of salt in the water due to recent dissolutioning activity is likely to be low, especially if the connate water is nearly saturated with respect to salt and a protective impervious cap exists around the dame. Another explanation for saline plumes is poor circulation and incomplete flushing of connate saline waters in the marine sedimentary aquifers surrounding salt dames. 
Other explanations offered for the occurrence of saline plumes include contamination from oil field operations (Ledbetter et al., 1975) and slow diffusion of salt fram the dame into stationary aquifer waters surrounding the dome (Netherland, Sewell, \& Assoc., Inc., 1976).

As in the case of surface salines, saline plumes may provide an indication of the hydrologic stability of a salt dome, however, detailed geohydrological investigations should be done to determine the cause of the plume.

Geologic and hydrologic investigations should determine the following: detailed stratigraphy and structure in the vicinity of the domes including thickness and lithology of sedimentary rocks, caprock, and sheath materials, and jointing and faulting adjacent to the dame; hydrologic properties of geohydrologic units, joints, fractures, caprock and sheath materials including potentionetric surfaces and gradients, aquifers and aquicludes, flow velocities, porosity, permeability, recharge and discharge zones and mechanisms, and hydrologic interconnections between geohydrologic units, salt domes, and surface waters; and groundwater quality along sides of domes, in adjacent sediments and in surface waters including salinity, chemistry, and temperature variations.

The investigations required to obtain this information may include, but are not restricted to, shallow and deep borings; subsurface sampling of salt, rocks, and groundwater; stratigraphic and structural mapping; surface and subsurface water quality testing, including salinity, chemistry, and temperature; electrical resistivity logging; seismic reflection and refraction surveys; pumping tests; potenticmetric surface mapping.

Using these data geohydrologic modeling analyses should be performed to improve understanding of groundwater flow patterns and rates within and between aquifers, recharge and discharge areas, and present and possible future areas of dissolutioning.

From these studies it should be possible to determine whether the salt formation is isolated from circulating waters by suitable impermeable formations preventing contact with, and potential dissolutioning of, salt. If circulating waters are in contact with the salt, these studies should provide a basis for estimating mechanisms and rates of existing or potential dissolutioning.

Candidate salt domes that are shown to be subject to active dissolutioning processes may still be acceptable sites for a repository, 
provided it can be established that the maximum estimated rates of dissolutioning are not sufficient to cause a breach of the integrity of the repository within the desired containment period. These projections should consider the fact that long-term tectonic, climatic, and environmental changes may alter present rates of dissolutioning.

Based on the information presented in this discussion, the screening specification for this criterion will be that the host salt dome must demonstrate hydrologic stability through detailed investigations.

The most favorable candidate dames are likely to be those that intrude a large thickness of relatively impermeable shale extending several hundred feet above and below the repository horizon; are encased in an impervious sheath, such as shale, clay, clay gouge; show no evidence of anomalous salinity distributions in surface or groundwaters; and pierce no aquifers that are unsaturated with respect to salt.

BASALT

$\underline{\text { Proposed Criterion }}$

The repository shall be located in a basalt rock that can be shown to have no hydrologic characteristics that have an adverse impact on the performance of the repository for the required period of contairment.

\section{Screening Specification}

The repository is acceptable for further study if the following hydrologic conditions are met: the rock unit in which the repository is to be located exhibits a low vertical and horizontal permeability and low flow velocity, the regional flow pattern and head conditions are well documented, the discharge area should be located a long distance from the repository site, the hydraulic head conditions should be below the regional water table with vertical flow: from the upper to the lower zones. The impact of surface flooding on the subsurface hydrologic regions should be documented. 
Basalt rocks generally consist of numerous lava beds laid down one upon another with intervening sedimentary interbed zones deposited during periods between successive flows (Mundorff et al., 1952; Newcomb et al., 1970). This sequence may range up to several thousand feet thick.

Lava flows contain original interstices (openings which may bear water) in the form of vesicles produced near the top by the expansion of steam or other gas during the process of congealing. These vesicles are largely isolated or communicate with one another only in isolated instances (Meinzer, 1923). Centers of lava beds may be massive and nonvesicular. Other possible original interstices include irregular cavities, produced as liquid lava beneath a surficlal crust moves away (lava tubes), and joints (columnar and other), as a result of shrinkage during cooling. The degree of interconnection of these interstices is variable. There may be rubbly basalt, ash, and cinders both above and below dense lava beds. Later deformation may produce imperfectly intersecting joints and cracks, which form secondary interstices for possible groundwater flow. The sedimentary interflow zones have permeabilities consistent with similar rock types in purely sedimentary enviroments. Compaction and the formation of secondary minerals may reduce original interstitial space. At places, interflow zores may contain interbeds of finely grained material of low permeability which retard the vertical movement of grouncwater.

Porosity in basalt sequences tends to be concentrated in interflow zones and in the tops and bottoms of most lava beds. The porosity of interior parts of the lava beds is small. In general, groundwater in basalts occurs under artesian pressure conditions. Permeability is normally concentrated in interflow zones and tops and bottoms of lave ieds, with interior parts of lava beds being of relatively low permeability or nearly impermeable. Permeability of basalt rocks is commonly heterogeneous and anisotropic (variable with horizontal and vertical distance and direction). Most of the permeability is parallel to lava beds and is greatest in the original flow direction (Davis, 1969). Flow tops may be permeable because of their highly jointed nature, the presence of cinders and rubble, and the existence of vesicles interconnected by joints and cracks. The lower parts of lava beds are permeable where irregular openings are present or where broken zones occur. Groundwater 
occurs and moves most commonly in these upper and lower parts of the basalt flows and in the permeable unconsolidated sediment of interflow zones. The dense interior parts of basalt flows do not generally transmit or store large quantities of groundwater. However; in some flows, these dense zones may be crossed vertically by joints and cracks. The degree of hydraulic connection between interflow zones varies considerably.

Additional information on the hydrologic characteristics of basalt and other volcanic rocks can be found in Walton et al. (1980) and Deju and Fecht (1979) .

Extensive geologic and hydrologic studies of the Columbia River Plateau at the Hanford Reservation have been conducted (National Acadeny of Sciences (NAS), 1978) to evaluate the management of radioactive wastes produced during plutonium refinement at the facility. The Hanford site is located in the Pasco Basin section of the Columbia River Plateau in south-central Washington. At the site, basalt flows separated by horizontal sedimentary interbeds of clay, silt and gravel achieve a composite thickness exceeding $3000 \mathrm{~m}$. The basalt sequence is overlain by the Ringold formation, consisting of a lower clay member and upper members of gravel and sand-silt with a typical thickness of $230 \mathrm{~m}$. Above the Ringold formation and extending to the ground surface are local glaciofluvial sands and gravels up to $120 \mathrm{~m}$ thick deposited during glacial meltwater flows (NAS, 1978).

The piezometric surface in the uppernost (to depths of about $1700 \mathrm{ft}$ ) confined basalts is trough shaped in the vicinity of the Hanford site about an axis coinciding roughly with the course of the Columbia River (Liverman, 1975). Recharge to upper basalts occurs locally where the water table is higher than the piezometric surface and from outside the Hanford site, including regional recharge from irrigation. Discharge is ultimately to the Columbia River. Elevations of piezometric head range from 500 to $350 \mathrm{ft}$ above mean sea level within the Hanford site, generally sloping toward the Columbia River .

Based primarily on water level data for deep wells within the Hanford Site, in general, the piezometric head decreases with depth at least to pre-Columbia River basalt group rocks (Piper, 1975; Deju and Fecht, 1979). Away from the Columbia River, the piezometric heads at great depths are below the water table; heads near the river are above the water table and the mean stage of the river. 
Deju and Fecht (1979) state that vertical flow in deep basalts is generally from the upper to lower zones. Horizontal flow is from west to east with discharge taking place from deep basalts below, or at the elevation of Lake Wallula, at least 60 miles from the Hanford site. The vertical permeabilities of the dense interiors of basalts range from 0.004 to $0.000001 \mathrm{ft} / \mathrm{d}$. In the Grand Ronde basalts the permeabilities of interflows and interbeds are generally as 10 as that of the dense basalt interiors.

The regional hydrologic system of horizontal and vertical movement in the deep basalts is, however, not fuliy understood and must be investigated further. Additional information concerning the hydrogeologic properties of sediments and rocks beneath the Pasco Basin is available in the following publications: Deju and Sumers, 1975; Deju and Ledgerwood, 1976; La Sala and Doty, 1970; Price, 1960; Agapito et al., 1977; Sumuers, 1978; Raymond and Tillson, 1968; Gephart et al., 1979; Tanaka, 1977; and Macnish and Barker, 1973.

The Hanford Site is located on the floodplain of the extinct glacial Lake Missoula which inundated the site to a level $250 \mathrm{~m}$ above the existing Columbia River during its maximum stage (NAS, 1978). Impoundment of Lake Missoula during future glaciation could drastically alter the existing groundwater flow. Recharge of the unconfined aquifer would induce seepage downward toward the confined aquifer beneath the hypothetical repository (Lake Missoula would not recharge the confined aquifer) with a velocity approaching $0.2 \mathrm{~m} / \mathrm{d}$, and groundwater at the repository would probably migrate to the confined aquifer in less than ten years. Subsequent flow within the aquifer would be controlled by permeability and horizontal gradients. If the properties of the aquifer were not affected by flooding, flow velocities between $0.0006 \mathrm{~m} / \mathrm{d}$ and $0.003 \mathrm{~m} / \mathrm{d}$ could be achieved. Depending on the location of discharge into the biosphere from the aquifer, flooding would appear not to pose a serious threat to this hypothetical repository because downward (rather than upward) seepage would be enhanced. However, little is known regarding groundwater flow within these deep, confined aquifers, and more studies of confined aquifer characteristics and locations of recharge and discharge near the Hanford site would be needed for a complete impact analysis. 
CRITERION 10 CFR 60.122(c) (1)

The site shall be selected so that to the extent practicable, the candidate area (ii) contains a host rock and surrounding confining units that provide: (c) geochemical properties, such as (1) reducing conditions which result in low solubility of radionuclides, and (2) nonextreme $\mathrm{pH}$ or a lack of complexing agents that promote high retardation of radionuclides.

ONWI 2.3 CRITERION III. SUBSURFACE HYDROLOGY AND GEOCHEMISTRY

2.3.1. The repository site shall be located so that the hydrological and geochemical regime will prevent radionuclides from leaving the repository and being transported to the biosphere in amounts or levels above those specified.

PROPOSED CRITERION

Groundwater in the repository host rock or in adjacent aquifers must have chemical characteristics such that canister corrosion, waste form dissolution and waste radionuclide migration are not pronoted.

SCREENING SPECIFICATION

The acceptable limits on groundwater chemical parameters shall be: $\mathrm{pH} 6.5-8$, neutral to slightly alkal.ine; Eh $\leq 100 \mathrm{mV}$, reducing conditions; complexing agents absent or in very low concentrations.

\section{DISCUSSION}

Groundwater geochemistry affects the performance of the waste disposal system in three ways. First, the stability of the canister is a function of canister and groundwater composition, with moderate ph and reducing conditions inhibiting corrosion (Ludeman et al., 1978). The stability of the waste is also dependent on groundwater chemistry and waste form. Second, for the case of spent fuel, where the dominant species is $\mathrm{wO}_{2}$, neutral to slightly basic 
pH with strongly negative eH will sharply inhibit dissolution (Wolery, 1980) . Optimal groundwater chemistry must be determined independently for each waste form. The third important impact of groundwater chemistry is on the migration of radionuclides away from the repository. Even under the best possible conditions, the canister and waste form will eventually dissolve once water has gained access to the repository. Thus liberated, the radionuclides will be free to migrate away from the repository until they are removed from the groundwater by the formation of relatively insoluble precipitates or by adsorption onto the materials making up the repository or the country rock. Isherwood (1979) has pointed out how adsorption is decreased by the formation of stable complexes in solution. In addition, high concentrations of many ionic species will decrease the effectiveness of whatever sorption capacity is present by competing for the sorption sites. For this reason, then, it is preferable if the groundwater at or near the repository is as pure as possible. However, some ions will combine with waste radionuclides to form highly insoluble species, so detailed site and waste form specific modeling calculations, such as those discussed by Wolery (1980), must be done to reach an acceptable ionic concentration limit.

For salt dome repositories, groundwater geochemistry takes on a somewhat different meaning than for repositories in insoluble rocks. The only water that should be present in an acceptable dome is that included as fluid inclusions in the salt, and possibly some hydration water bound to clay or gypsum impurities in the salt. The chemistry of groundwater outside of an unflawed dome is not significant in the respects discussed above because any failure of the dome that would let groundwater contact the waste would cause that groundwater to approach salt saturation. The effects of this type of event should not be mitigatable by any prior screening of regional groundwater geochemistry. However, groundwater chemistry is a significant factor in screening domes with respect to hydrological stability (GEI, 1980c).

\section{GEOCHEMISTRY--ROCK}

CRITERION 10 CFR 60.122 (b) (4)

There is an absence of geochemical properties that provide a major barrier to the movement of most radionuclides between the repository and 
accessible environment. (Potential adverse condition--the presence of any of the potentially adverse conditions shall give rise to a presumption that the geologic repository will not meet the performance objectives.)

ONWI 2.3 CRITERION III. SUBSURFACE HYDROLOGY AND GEOCHEMISTRY

2.3.1. The repository site shall be located so that the hydrological and geochemical regime will prevent radionuclides from leaving the repository and being transported to the biosphere in amounts or levels above those specified.

\section{PROPOSED CRITERION}

The host rock of the repository and surrounding rock masses must have chemical characteristics such that canister corrosion, waste form dissolution and waste radionuclide migration are not promoted.

\section{SCREENING SPECIFICATION}

The rock masses through which groundwater might transport dissolved nuclear waste should either restrict such migration by adsorbing the waste or by promoting the formation of insoluble, immobile compounds, or should at least not alter the groundwater chemistry so as to make other rock units less effective as barriers to waste migration.

\section{DISCUSSION}

In order to provide the best environment for nuclear waste disposal, it is important that the repository rock, and the rock making up the surrounding aquifers, interact with dissolved radionuclides to retard migration of the waste in the groundwater system. Each rock mass need not necessarily act as a chemical barrier to waste migration, but each mass must not affect the groundwater chemistry so as to reduce the effectiveness of other barriers. This means that the retardation capability of nearby rocks should not be significantly impaired by interactions between a rock mass and the groundwater, and the groundwater should not be more inimical to the waste form and package after contact with the rock mass. It is also important to 
consider the potential effects of waste-induced heat and radiation on the chemistry of the rock mass around the repository.

The characteristics that make a rock mass a chemical barrier to nuclear waste migration include retardation, ion filtration, and solubility inhibition capabilities. These factors are discussed in some detail by Isherwood (1979). Although all rock misses have some retardation capability, the presence of minerals with high ion exchange capacity, such as zeolites and many clays, will greatly increase the effectiveness of the rock as a barrier to nuclide migration. Rocks such as shales and siltstones cosionly contain these minerals in abundance. Zeolites and clays are also common low-temperature alteration products which form in fractures and cavities in rocks such as basalt, tuff, granite, and shale. The presence of extensive secondary mineralization in a fractured rock mass might make such rock acceptable for repository development even though the presence of fractures might raise the hydraulic conductivity to unacceptable levels.

Even if the rock in which the repository is located does not have appreciable retardation capability, it is important that the rock mass not have deleterious effects on the retardation provided by adjacent geologic or hydrologic units. If the groundwater carrying radionuclides is highly saline, the retardation of rocks in contact with that groundwater would be much less effective than in the case of more dilute groundwater. However, clay layers surrounding saline water sources may suppress the migration of dissolved constituents through ion filtration (Isherwood, 1979).

It is possible for nuclear wastes to form soluble or insoluble stable complexes with waste constituents of the groundwater or of the country rock. If these complexes are insoluble, the waste constituents are removed from the groundwater system and will not migrate to the accessible environment. However, soluble complexes are often not retarded, and so will reach the enviromment much more quickly than metal ions, such as waste radionuclides. Many organic compounds will form very stable soluble complexes with radionuclide ions. Therefore, organic material bearing rocks should be avoided when selecting sites.

In adaition to selecting sites with existing geochemical conditions favorable to waste containment, it is important to consider any changes that might occur because of radiolytic or thermal effects induced by the waste. clay minerals and zeolites dehydrate at relatively low temperatures lless than 
$200^{\circ} \mathrm{C}$ for zeolites and less than $400^{\circ} \mathrm{C}$ for clays); so the retardation capacity of these minerals will be greatly reduced in the immediate vicinity of the waste. Thermal analytical modeling is necessary to predict how extensively temperatures adequate to break down ion exchanging mineral species might be distributed. Radiolytic effects on mineral lattices of interest are unknown, so research is needed to determine the extent of degradation of retardation that might be expected near stored waste.

Different rock types present very different geochemistries for waste disposal. In general, salt is infer or to other media. Groundwater in sontact with waste in salt will be a saturated brine, and so will tend to defeat the natural retardation barrier provided by the surrounding geologic strata. In addition," domed salt often contains, or is closely associated with, small but possibly significant amounts of organic material, usually hydrocarbons, which can form stable complexes with waste radionuclides. On the other hand, basalt flows commonly have porous zones in which zeolites and clays have formed. These minerals are also common in the interflow zones which form aquifers. The presence of extensive quantities of these ion exchengers will help to ensure that wastes will be significantly retarded, should they escape the repository.

IGNEOUS ACTIVITY

CRITERION 10 CFR 60.122 (b) (2) (vii)

A repository shall not be located where there is evidence of intrusive igneous activity since the start of the Quaternary Period.

ONWI CRITERION 2.2 .3

The repository site shall be located so that centers of Quaternary igneous activity can be identified and shown to have no unacceptable adverse impact on repository performance. 
PROPOSED CRITERTON

The repository shall not be located in an area where volcanism or. igneous intrusion can compromise the safety of operations or the geological containment.

SCREENING SPECIF ICATION

A repository site is acceptable for further study if the following conditions are met: the site is beyond the maximun range of Quaternary volcanic flow deposits (lava flows, pyroclastic flows, and lahars), the patterns of Quaternary ash deposits indicate that ashfalls at the site would not be of sufficient thickness to compromise the safety of repository operations, and no geological evidence indicates future igneous intrusion within the time span necessary for geologic containment.

DISCUSSION

Extrusive volcanic deposits are a potential threat to surface waste handling facilities of a repository during their relatively short operational lifespan. After the surface facility has been dismantled and the repository has been sealed, extrusive volcanism would not have significant adverse impact on geologic containment. Igneous intrusions, on the other hand, could conceivably cause the transport of waste directly to the surface at any time during the necessary containment period.

This screening specification bears no relevance to Gulf Coast salt domes because the eritire Gulf coast area has not been subject to any igneous activity since the end of the Cretaceous Period (Brunton et al., 1978). Therefore, no screening specification regarding igneous activity is required for damed salt.

Volcanism that produced the massive flood basalts of the Columbia River Plateau occurred during the mid-Miocene Epoch from 17 to 13 million years ago (Armstrong, 1978; Christiansen and McKee, 1978). More recent intracanyon basalt flows have been erupted up until approximately 6 million years ago, but these probably account for less than 18 to the total volume of Columbia River Plateau basalts (Mckee and Swanson, 1977). No basalts have erupted in the 
plateau during the past 6 million years, and no ancmalous geothermal or geophysical data exist to indicate the possibility of future igneous activity. The plateau is bounded on the west by the Cascade volcanic chain, on the south by the High Lava Plains, and on the east by the Snake River Plain, all of which experienced volcanism during the Quaternary Period. Cascade volcanism has been restricted to vents of the major Quaternary volcanoes that are aligned within a few kilameters of the axis of the Cascade Range. Future Cascade volcanism is likely to remain restricted to vents along these axes. Volcanic flow deposits have been confined to slopes of the major Cascade volcanoes, with some pyroclastic and mudflow deposits extending up to $70 \mathrm{~km}$ down stream-valleys that radiate from the volcanoes (Crandell, 1971). Explosive eruptions from these Quaternary volcanic centers, particularly the Cascade Range, could produce significant thicknesses of ash on adjacent portions of the Columbia River Plateau (Crandell and Mullineaux, 1975). Analysis of ash deposits from Mount st. Helens, the most active Cascade volcano, reveals that ash layers associated with the largest eruptions are generally thinner than $20 \mathrm{~cm}$ at distances greater than $100 \mathrm{~km}$ downwind from the volcano. Ash thicknesses up to several tens of centimeters would probably temporarily disrupt surface operations at a repository, but would not threaten the safety of operations. Ash deposits pose a potential hazard only to repository sites on the extreme western and southern margins of the Columbia River Plateau. Central areas of the plateau, such as the Pasco Basin, could anticipate ash deposits a few centimeters thick during a major Cascade volcanic eruption.

Potential repository sites in the Columbia River basalts should be acceptable with regard to volcanism, except for potential sites near Quaternary volcanic centers along the western and southern margins of the Plateau. Sites within $100 \mathrm{~km}$ of Quaternary volcanic centers require more detailed studies to define the hazards posed by extrusive volcanism. A more detailed discussion of this issue is presented by GEI (1980a) . 
CRITERION 10 CFR 60.122(b) (l) FOTENTIALLY ADVERSE HUMAN ACTIVITISS

(i) There is or has been conventionai or in situ subsurface mining for resources. (ii) There is or has been drilling for whatever purpose, except holes drilled for investigations of the geologic repository, to depths below the lower limit of the accessible environment. (iii) There are resources which are economically exploitable using existing technology under present market conditions. (iv) Based on a resource assessment, there are resources that have either higher gross or net value than the average for other areas of similar size in the geologic province in which the geologic repository is located. Determinations of net value shall consider development, extraction, and marketing costs. The resource assessment shall include both known and undiscovered deposits of all resources within the geologic province that includes the site and that (1) have been or are being exploited, or (2) have not been exploited but are exploitable under present technology and market conditions.

\section{ONHI 2.7 CRITERION VII. HUMAN INIRUSION}

The repository site shall be located so that likelihood or consequences of past or future human intrusion will cause no unacceptable adverse impact to repository performance.

2.7.1. The repository site shall be located sc that future intrusion due to the site's containing, or appearing to contain, economically exploitable deposits of petroleum or mineral resources would not cause an unacceptable adverse impact on repository performance.

2.7.2. The repository site shall be located so that the exploration history of the site can be defined and can be shown to have no unacceptable adverse impact on repository performance. 
No quantitative limit on the value of contained resources can be proposed for any medium. The economic factors are extremely site- and marketdependent, so a thorough resource investigation must be conducted at every proposed site or area.

\section{DISCUSSION}

General discussions of natural resource-related effects on nuclear waste repositories have been presented by Robbins (1980), Golder Associates, Inc. (1980), Wagoner and Steinborn (1979), and Carpenter et al. (1979). A detailed discussion of resource problems for bedded salt repositories is contained in GEI (1978). This discussion will therefore be limited to a summary of potential resource problens relevant to basalt and domed salt repositories.

Salt domes make up a tectonic and structural setting well known for association with valuable natural resources. Halbouty (1967) has presented a detailed discussion of salt with special emphasis on petroleur resources. In brief, salt domes have been targets for exploration in the past, are currently in production or active exploration for resources, are contemplated as sites for petroleum reserve storage, and may present an attractive target for resource exploration in the future long after administrative control of the disposal site is lost. It should be noted that nearly all natural resource production associated with domes has been from the caprock on top of the dome, sediments distorted by dome intrusion, and fram sediments lying under overhanging dome lobes. The only exceptions to these locations are the production of salt, by conventional or solution mining, fram the heart of the domes, and the development of space in the dome interior for the storage of petroleum and other nonaqueous fluids. The Gulf Coast region contains several hundred salt domes, so withdrawing a $f e w$ of these would not significantly reduce the total resource of halite (salt) available. The "attractive target" concept suggests that this may not be sufficient to pern. : comes to be used as potential waste disposal sites. It has been stated repeatedly by many authors that detailed searches of available data as well as geophysical searches must be undertaken to determine the exploration and mineral development history of each dome selected as a candidate site. 
The natural resources associated with basalt flows are quite different. Two types of resources must be considered--those directly associated with the basalt sequence, and those in the basement rock underlying the flows. Resources located in or between the flows include fresh water and possibly thermal water. Shallow aquifers are commonly tapped to provide agricultural and domestic water supplies. Enough water appears to be available at shallow levels to preclude the necessity of tapping aquifers at depths that may have some impact on a repository. Only a relatively insignificant amount of mineral resources are associated with plateau basalts. Zeolite deposits occasionally occur in mineable concentrations on flow surfaces or in interflow gravels, but market conditions are such that extensive exploratory drilling and production of zeolites deep in the basalt pile is not expected in the foreseeable future. Surface mining for clay and construction gravei is also common, but deep mining is not anticipated. Basalt also contains a very significant amount of iron and titanium, but in silicate matrices that make extraction extremely expensi ve.

The basement rock underlying basalt basins may contain extensive hidden resources. Hydrocarbon exploration on structural trends in the basement has occurred, but with very little success to this point. Areas of potential future interest for hydrocarbons may be avoided by geophysical surveys of the basement structures. Mineral deposits such as uranium or copper may be assumed to be present in the older basenent rocks, especially in the north end of the basin, but the cost of mining such deposits located beneath thousands of meters of basalt in the basin interior would be prohibitive. No economically important metal mineralization is directly associated with the plateau basalts. 
Agapito, J. E., M. P. Hardy, and P. R. St. Laurent, 1977, Geoengineeering Review and Proposed Program Outline for the Structural Design of a Radioactive Waste Repository in Columbia Plateau Basalts, Rockwell Hanford Operations, Richland, Wash., RHO-ST-6.

Algermissen, S. T., 1969, "Seismic Risk Studies in the United States," in $\underline{4 t h}$ World Conf. on Earthquake Eng., Santiago, Chile.

Anderson, R. E., D. Eargle, and B. O. Davis, 1973, Geologic and Hydrologic Summary of Salt Domes in Gulf Coast Region of Texas, Louisiana, Mississippi, and Alabama, U.S. Geol. Sur. Open File Rep.

Armstrong, R. L., 1978, "Cenozoic Igneous History of the U.S. Cordillera from Latitude $42^{\circ}$ to $49^{\circ} \mathrm{N}, "$ Geol. Soc. Am. Memoir 152, 265.

Atlantic Richfield Hanford Company, 1976, Preliminary Feasibility Study on Storage of Radioactive Wastes in Columbia River Basalts, Research and Engineering Division, Richland, Wash., ARH-ST-137.

Bechtel National, Inc., 1978, Regional Environmental Characterization Reports for the Gulf Interior Region and Surrounding Territory, report to office of Nuclear Waste Isolation, Battelle Memorial Institute, Columbus, Ohio, ONWI//SUB/78/512-01600-1.

Benson, L. V., 1978, Secondary Minerals Oxidation Potentials, Pressure and Temperat:ure Gradients in the Pasco Basin of Washington State. Lawrence Berkeley Laboratory, Berkeley, Calif., RHO-BWI-C-34.

Billings, M., 1972, Structural Geology (Prentice-Hall, Inc., Englewood Cliffs, N.J.).

Birch, F., J. F. Schairer, and H. C. Spicer, Eds., 196I, Handbook of Physical Constants, Geol. Soc. Am. Spec. Pap. No. 36.

Bloom, A. I., 1978, Geomorphology--A Systematic Analysis of Late Cenozoic Landforms (Prentice-Hall, Inc., Englewood Cliffs, N.J.).

Brown, L., 1978, "Recent Vertical Crustal Movements Along the East Coast of the U.S.," Tectonophysics 44, 205.

Brown, L., and J. Oliver, 1976, "Vertical Crustal Movements from Leveling Data and Their Relationship to Geologic Structure in the Eastern U.S.," Rev. Geophys. and Spac. Sci. 14, 13.

Brown, R., 1969, "Some Suggested Rates of Deformation of the Besalts in the Pasco Basin and Their Implications," in Proc. 2nd Columbia River Basalt Sym. (Eastern Washington State College Press, Cheney).

Brunton, G. D., R. B. Laughon, and W. C. Mcclain, 1978, Screening Specifications for Gulf Coast Salt Domes, Department of Energy, Y/OWI/TM-48. 
Camp, V. E., S. M. Price, and S. P. Reidel, 1973, Descriptive Sumary of the Grande Ronde Basalt Type Section, Columbia River Basalt Group, U.S. Energy Research and Development Adninistration, Washingtón, D.C., RHO-BWI-LD-15.

Carpenter, D. W., T. L. Steinborn, and L. D. Thorson, 1979, Groundwater Recharge and Discharge Scenarios for a Nuclear Waste Repository in Bedded Salt, Lawrence Livermore National Laboratory, Livermore, Calif., UCID-18119.

Castle, R., et al., 1976, "Aseismic Uplift in Southern California," Science 192, 251.

Christiansen, R., and E. McKee, 1978, "Late Cenozoic Volcanic and Tectonic Evolution of the Great Basin and Columbia Intermountain Regions," Geol. Soc. Am. Memoir 152, 283.

Claiborne, H. C., and F. Gera, 1977, Potential Containment Failure Mechanisms and Their Consequences at a Radioactive Waste Repository in Bedded Salt in New Mexico, Oak Ridge National Laboratory, ORNL-TM-4639.

Crandell, D., 1971, Postglacial Lahars from Mt. Rainier Volcano, Washington, U.S. Geophys. Soc. Prof. Pap. 677.

Crandell, D., and D. Mullineaux, 1975, Technique and Rationale of Volcanic Hazards Appraisal in the Cascade Range, Northwestern U.S.," Environ. Geol. 1, 23.

Dames and Moore, 1978, Technical Support for GEIS: Radioactive Waste Isolation in Geologic Formations. Vol. 7. Baseline Rock Properties-Basalt, report to U.S Department of EnergY, Y/OWI/TM-36/7.

Davis, S. N., 1969, "Porosity and Permeability of Natural Materials," in Flow Through Porous Media, R. J. M. DeWest, Ed. (Academic Press, New York).

Deju, R. A., 1977, A Plan to study the Environmental Factors Needed to Establish the Feasibility of Storing Radioactive Waste in Columbia River Basalts, Atlantic Richfield Hanford Operations, Richland, Wash., ARH-ST-152.

Deju, R. A., and K. R. Fecht, 1979, Preliminary Description of Eyperbolic Characteristics and Contaminant Transport Potential of Rocks in the Pasco Basin, South-Central Washington, Rockwell Banford Operations, Richland, Wash., RHO-BWI-LD-20.

Deju, R. A., and R. I. Ledgerwood, 1976, Hydrology of the Uppermost Confined Aquifers Underlying the Hanford Reservation, Atlantic Richfield Hanford Co., Richland, Wash., ARH-SA-253.

Deju, R. A., and W. R. Sumers, 1975, Transmissivity and Hydraulic Conductivity of Saturated sedimentary Rocks in the Hanford Reservation, Atlantic Richfield Hanford Company, Richland, Wash., ARH-C-00007. 
Durney, D., and J Ramsay, 1973, Incremental Strains Measured by Syntectonic Crystal Growths, Gravity and Tectonics; $K$. Dejong and $R$. Scholten, Eds. (John Wiley and Sons, Inc., New York):

Fischer, A. G., and Judson, S., 1975, Petroleum and Global Tectonics

(Princeton University Press, Princeton, N.J.).

Flint, R. F., 1975, Glacial and Pleistocene Geology (John W1lè and Sons, Inc., New York).

Friedman, I., and W. Long, 1976, "Hydration Rate of Obsidian," Science 191, 347.

Geotechnical Engineers, Inc. (GEI), 1978, Uncertainties in the Detection, Measurement and Analysis of Selected Features Pertinent to Deep Geologic Repositories, report to Lawrence Livermore National Laboratory, Livermore, Calif., UCRL-13912.

Geotechnical Engineers, Inc. (GEI), 1980a, Report on the State-of-the-Art for Evaluating the Impact of Tectonism and Volcanism on a Radioactive Waste Repository, report to Lawrence Livermore National Laboratory, Livermore, Calif.

Geotechnical Engineers, Inc. (GEI), 1980b, Report on the state-of-the-Art for Evaluating the Potential Impact of Flooding on a Radioactive Waste Repository, report to Lawrence Livermore National Laboratory, Livermore, Calif.

Geotechnical Engineers, Inc. (GEI), 1980c, Report on the state-of-the-Art for Evaluating the Poteniial Impact of Diapirism on a Radioactive Waste Repository, report to Lawrence Livermore National Laboratory, Livermore, Calif.

Geotechnical Engineers, Inc. (GEI), 1980d, Report on the State-of-the-Art for Evaluating the Potential Impact of Erosion or a Radioactive Waste Repository, report to Liwrence Livermore National Laboratory, Livermore, Calif.

Gephart, R. E., R. A. Deju, and P. A. Eddy, 1979, Geophysical Logging and Hydrologic Testing of Desp Basalt Flows in the Rattlesnake Hills Well No. 1, Rockwell Hanford Operations, Richland, Wash., RHO-BWI-ST-l.

Golder Associates, Inc., 1977, Second Report: Development of Site Suitability Criteria for the High Level Waste Repository (Preliminary), report to Lawrence Livermore National Laboratory, Livermore, Calif., UCRI-13793.

Halbouty, M. T., 1967, Salt Domes--Gulf Region, United States and Mexico (Gulf Publishing Co., Houston).

Hardy, M. D., C. M. St. John, and G. Hocking, 1973, Numer ical Modeling of Rock Stresses Within a Basaltic Nuclear Waste Repository. Phase I: Problem Definition, Rockwell Hanford Operations, Richland, Wash., RHO-BWI-C-24.

Bobbs B., et al., 1976, An Outline of Structural Geology (John Wiley and Sons, Inc., New York). 
Howard, A. D., 1967, "Drainage Analysis in Geologic Interpretation: A Summation," Am. Assoc. Pet. Geol. Bull. $5(11)$, 2246-2259.

International Atomj.c Energy Agency (IAEA), 1977, Site Selection Factors for Repositories of Solid High-Level and Alpha-Bearing Wastes in Geologic Formations, I.A.E.A. Tech. Rep. 177.

Isherwood, D. J., 1979, Geoscience Data Base Handbook for Modeling a Nuclear Waste Repository. Vol. 1. NUREG/CR-0912, Lawrence Livermore National Laboratory, Livermore, Calif., UCRL-52719(1) .

John, B. S., 1979, "Planet Earth and Its Seasons of Cold," in The Winters of the World (Halstead Press, Chichester, England).

Judson, S., and R. F. Ritter, 1964, "Rates of Regional Denudation in the United States," J. Geophys. Res. 69, 3395-3401.

LaSala, Jr., A. M., and G. C. Doty, 1970, Preliminary Evaluation of Hydrologic Factors Related to Radioactive Waste Storage in Basaltic Rocks at the Hanford Reservation, Washington, U.S. Geol. Surv. Open File Rep., in Cooperation with the A.E.C.

Law Engineering Testing Company, 1978, National Waste Terminal Storage Program. Geologic Evaluation of Gulf Coast Salt Domes, Site Selection Program Plan for the Office of Waste Isolation, report to Union Carbide Corporation-Nuclear Division, ONWI LIB 0092.

Ledbetter, J. O., ผ. R. Kaiser, and E. A. Ripperger, 1975, Radioactive Waste Management by Burial in Salt Domes, Engineering Mechanics Research Laboratory, University of Texas, Austin.

Lee, W. L. L., K. Nair, and G. Smith, 1978, Basalt Waste Isolation Description Events Analysis, Woodward-Clyde Clyde Consultants, San Francisco, RHO-BWI -C-43.

Liverman, J. L., 1975, Final Environmental Statement--Waste Management Operations, Hanford Reservation, Richland, Washington, U.S. EnergY Research and Development Administration, Washington, D.C., ERDA-1538.

Ludeman, W., L. Abrego, and D. McCright, 1978, Corrosion Studies on Retrievable Spent Fuel Containers: A Progress Report, Lawrence Livermore National Laboratory, Livermore, Calif., UCID-17917.

Machette, M., 1978, "Dating Quaternary Faults in the Southwest United states Using Buried Calcic Paleosols," J. Res. U.S. Geol. Surv. 6(3), 369.

Macnish R. D., and R. A. Barker, 1973, Ligital Simulation of a Basalt Aguifer System, Walla Walla River Basin, Washington and Oregon, Department of Ecology, Washington state University, Olympia.

Martinez, J. D., et al., 1975, An Investigation of the Utility of Gulf Coast Salt Domes for the Storage and Disposal of Radioactive Wastes, Institute of Environmental Studies, Louisiana State University, Baton Rouge, ORNL/SUB-4112/10. 
Martinez, J. D., et al., 1976, An Investigation of the Utility of Gulf Coast salt Domes for the storage and Disposal of Radioactive Wastes, Institute of Environmental Studies, Louisiana State University, Baton Rouge, report to Office of Waste Isolation, Union Carbide Corporation-Nuclear Division, and U.S. Department of Energy, ORNL/SUB-4112/25.

Martinez, J. D., et al., 1977, An Investigation of the Utility of Gulf Coast Salt Domes for the Storage and Disposal of Radioactive Wastes, Institute of Environmental studies, Louisiana state University, Baton Rouge, report to Office of Waste Isolation, Union Carbide Corporation-Nuclear Division, and U.S. Department of EnergY, Y/OWI/SUB-4112/37.

Mckee, E., and D. Swanson, 1977, "Duration and Volume of Columbia River Basalt Volcanism, Washington, Oregon, and Idaho," Geol. Soc. Am. Abs. with Prog. $9(4), 462$.

Meinzer, D. E., 1923, "The Occurrence of Groundwater in the United States," U.S. Geol. Surv. Water Supply Pap. 489.

Mescherikov, J., 1967, "kecent Crustal Movenents in Seismic Regions--Geodetic and Geomorphic Data," Tectonophysics 6, 29.

Milliman, J. D., and K. O. Emery, 1968, "Sea-Levels During the past 35,000 Years," Science 162, 1121-1123.

Mundorff, M. J., D. J. Reis, and J. R. Strand, 1952, Progress Report on Ground Water in the Columbia Basin Project, Washington," U.S. Geol. Surv. Open File Rep.

National Academy of Sciences (NAS), 1978, Radioactive Wastes at the Hanford Reservation-A Technical Review, Comnittee on Radioactive Waste Management, National Research Council, Washington, D.C.

National Research Council/National Academy of Sciences (NRC/NAS), 1978, Geological Criteria for Repositories for High-Level Radioactive Waste, Washington D.C.

Netherland, Sewell \& Assoc., Inc." 1976, Geologic Study of the Interior Salt Domes of Northeast Texas Basin to Investigate Their stability for Possible Storage of Radioactive Waste Material, report to office of Waste Isolation and Union Carbide Corporation, Y/OWI/SIJB-76/99939.

Newcomb, R. C., J. R. Strand, and F. J. Frank, 1970, Geology and Ground-Water Characteristics of the Hanford Reservation of the U.S. Atomic Energy Commission, Washington, U.S. Geol. Surv. Open File Rep.

Oak Ridge National Laboratory (ORNL), 1973, sice Selection Factors for the Bedded salt pilot Plant, submitted to U.S. Energy Research and Development Administration, ORNL/TM-4219.

Office of the Federal Register (OFR), 1980, 10 CFR 60, U.S. National Archives and Records Service, General Services Administration, Washington, D.C. 
Office of Nuclear waste Isolation (OWNI), 1980, ONWI 32 (2): NWTS Criteria for the Geologic Disposal of Nuclear Wastes: Site Qualification Criteria, prepared for Department of Energy, Washington; D.C., EY-76-C-06-1830.

Parsons, Brinckerhoff, Quade, \& Douglas, Inc. (PBQ\&D), 1978, Technical Support for GEIS: Radioactive Waste Isolation in Geologic Formations. 14. Repository Preconceptual Design Studies: Basalt, submitted to Department of Ener gy, Y/OWI/TM-36/14.

Patton, P. C., and U. R. Baker, 1978, "New Evidence for Pre-Wisconsin Flooding in the Channeled Scabland of Eastern Washington", Geology 6, 567-571.

Peck, J., 1980, Fluid Inclusion Studies for Dating Fault Movement, Program with Abstracts, Geotechnology in Massachusetts, Department of Geology and Geography, University of Massachusetts, Amherst.

Piper, A. M., 1975, Hypothetical Prototype Sites of Repositories for Radioactive Wastes: Flood Basalt, Office of Waste Isolation, Union Carbide Corporation, report to U.S. Energy Research and Development Administration, Y/OWI/SUB-3745/6.

Prescott, W., and J. Savage, 1973, Progress Report on Geodolite Measurements at Hanford, Washington, Informal Report, National Center for Earthquake Research, U. S. GS, Reston, Va.

Fıess, F., and R. Siever, 1974, Earth (W. H. Freman and Company, San Francisco).

Price, C. W., 1960, Artificial Recharge of a Well Tapping Basalt Aquifers, Walla Walla Area, Washington, Water Supply Bull. 7, Department of Ecology, Washington State University, Pullman.

Raymond, J. R., and D. D. Tillson, 1968, Evaluation of a Thick Basalt Seguence in South-Central Washington, Battelle Northwest Laboratories, Richland, Wash., BNWL-776.

Richmond, G. M., R. Frydell, G. E. Neff, and P. I. Weis, 1965, "The Cordelleran Ice sheet of the Northern Rocky Mountains and Related Quaternary History of the Columbia Plateau," in The Quaternary of the United States, H. E. Wright and D. G. Grey, Eds. (Princeton Press, Princeton, N.J.).

Rockwell Hanford Operations, 1978, Basalt Waste Isolation Program Annual Report: Fiscal Year 1978, Informal Report by the Basalt Waste Isolation Program Staff, submitted to the Department of EnergY, RHO-BWI-78-100.

Rosen, A., 1976, Response of Rock Tunnels to Earthquake Shaking, M.s. thesis, Massachusetts Institute of Technology, Cambridge.

Smith, Jr., C. G., 1977, "Hydrologic Stability of Salt Dames," in Salt Dome Utilization and Environmental Considerations, symp. proc. sponsored by Institute of Environmental Studies, Louisiana State University, Baton Rouge, Nov. 22-24, 1976. 
W.D. Summers and Assoc., 1978, A Survey of the Ground-Water Geology and Bydrology of the Pasco Basin, Washington, Rockwell Hanford Operations, Richland, Wash., RHO-BWI-C-41.

Tanaka, H. ㅂ. , 1977, Aguifer Test of Well 18/25-15E in Grant County, Washington, Department of Ecology, Washington State University, Olympia.

Thornbury, W. D., 1957, Principles of Geomorphology (John Wiley and Sons, Inc., New York), 3rd ed.

Tillson, D., 1970, Analysis of Crustal Changes in the Columbia Plateau from Contemporary Triangulation and Leveling Measurements, Battelle Northwest Laboratories, Richland, Wash., BNwL-CC-2174.

Trimble, S. พ., 1977, "The Fallacy of Stream Equilibrium in Contemporary Denudation Studies, Am. J. Sci. 277, 876-887.

Hagoner, J. L., and T. L. Steinborn, 1979, Preliminary Area Selection Considerations for Radioactive Waste Repositories in Bedded Salt, Lawrence Livermore National Laboratory, Livermore, Calif., OCID-18122.

Walton, W.C., M. L. Voorhees, and T. A. Prickett, 1980, Conceptuc.l Mode Eor Regional Radionuclide Transport from a Basalt Repository, Camp, Dresser \& Mckee, Inc, report to Lawrence Livermore National Laboratory, Livermore, Calif. . UCRL-15250.

Willard Owens Assoc., Inc., 1979, Geoscience Parameter Data Base Handbook: Granites and Basalts, submitted to Lawrence Livermore National Laboratory, Livermore, Calif., .SRL-15152.

Wolery, T. J., 1980, Chemical Modeling of Geologic Disposal of Nuclear Waste: Progress Report and a Perspective, Lawrence Livermore National Laboratory, Livermore, Calif., UCRL-52748. 